\title{
The missing risk premium in exchange rates
}

\author{
Magnus Dahlquist ${ }^{\mathrm{a}, \mathrm{b}, *}$, Julien Pénasse ${ }^{\mathrm{c}}$ \\ a Stockholm School of Economics, Drottninggatan 98, Stockholm SE-111 60, Sweden \\ ${ }^{\mathrm{b}}$ Centre for Economic Policy Research (CEPR), London, UK \\ ' University of Luxembourg, 6, rue Richard Coudenhove-Kalergi, Luxembourg L-1359, Luxembourg
}

\section{A R T I C L E I N F O}

\section{Article history:}

Received 27 October 2020

Revised 10 March 2021

Accepted 5 April 2021

Available online 7 July 2021

\section{JEL classification:}

E43

F31

G15

\section{Keywords:}

Currency return

Forward premium puzzle

Purchasing power parity

State-space model

Uncovered interest rate parity

\begin{abstract}
A B S T R A C T
We use a present-value model of the real exchange rate to impose structure on the currency risk premium. We allow the currency risk premium to depend on both the interest rate differential and a latent component: the missing risk premium. Consistent with the data, our present-value model implies that the real exchange rate should predict currency returns. We find that the missing risk premium, not the interest rate differential, explains most of the variation in the real exchange rate. Moreover, our model sheds light on puzzling relations between the interest rate differential, the real exchange rate, and the currency risk premium.
\end{abstract}

(c) 2021 The Authors. Published by Elsevier B.V. This is an open access article under the CC BY license (http://creativecommons.org/licenses/by/4.0/)

\section{Introduction}

It is well-established that uncovered interest rate parity (UIP) does not hold for major currencies. Currencies with positive interest rate differentials tend to appreciate, whereas UIP predicts that they depreciate. A common interpretation of deviations from UIP is that currencies command an interest-rate-dependent risk premium: currencies

\footnotetext{
मf We thank Patrick Augustin, Philippe Bacchetta, Federico Bandi, Drago Bergholt, John Campbell, Mike Chernov, Max Croce, Pasquale Della Corte, Charles Engel, Benjamin Holcblat, Peter Hördahl, Hanno Lustig, Roberto Marfè, Ian Martin, Tyler Muir, Tarun Ramadorai, Robert Richmond, Valeri Sokolovski, Rosen Valchev, Andrea Vedolin, Adrien Verdelhan, Colin Ward, Irina Zviadadze, an anonymous referee, and various participants in seminars and conferences. Dahlquist gratefully acknowledges support from the Jan Wallander and Tom Hedelius Foundation, and the Swedish House of Finance at the Stockholm School of Economics.

* Corresponding author at: Stockholm School of Economics, Drottninggatan 98, SE-111 60 Stockholm, Sweden.

E-mail address: magnus.dahlquist@hhs.se (M. Dahlquist).
}

with relatively high interest rates are riskier for investors (Fama, 1984).

In this paper, we use a present-value model to impose structure on the currency risk premium. We argue that the currency risk premium depends on another, latent component that is imperfectly correlated with the interest rate differential. When purchasing power parity (PPP) holds, the present-value approach decomposes the real exchange rate into the sum of all expected future interest rate differentials minus the sum of all future currency risk premiums (Campbell and Clarida, 1987; Engel and West, 2005; 2010). Building on this approach, Menkhoff et al. (2017) show that the real exchange rate has predictive power for the cross-section of currency returns. Allowing for a missing risk premium component in a present-value model has similar implications for the time series of currency returns. In a simple present-value model, we show that traditional Fama (1984) regressions have an omitted variable, which closely relates to the real exchange rate. Our result echoes the well-known result that the price-dividend ratio 


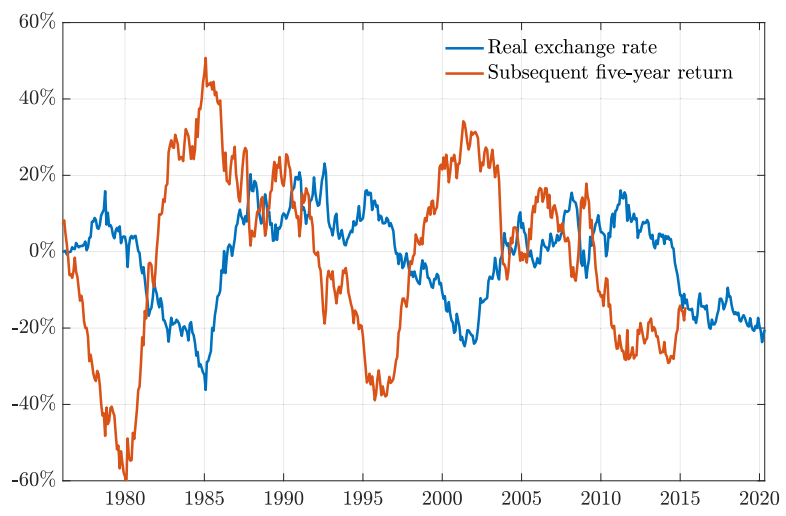

Fig. 1. Real exchange rates and subsequent five-year currency returns. This figure shows the demeaned log real exchange rate expressed in dollars per unit of foreign currency (in blue) and the subsequent five-year dollar return for an equal-weighted currency portfolio of seven currencies (in red). The long-term mean of the real exchange rate is computed in real time using an expanding window, and thus starts at zero. (For interpretation of the references to color in this figure legend, the reader is referred to the web version of this article.)

predicts future stock returns. In the context of exchange rates, PPP implies that the real exchange rate plays a role similar to that of the price-dividend ratio.

As the missing risk premium is more persistent than the interest rate differential, the real exchange rate becomes increasingly important as the forecasting horizon increases. Fig. 1 illustrates this point. It plots the log real dollar price of a portfolio of seven major currencies (in blue) along with the portfolio's subsequent five-year return (in red). For example, in 1985 foreign currencies appeared particularly cheap after a period of dollar appreciation. The subsequent return on investing in foreign currencies was particularly high, a pattern that repeats itself over time. This pattern is reminiscent of the predictive relation between valuation ratios and subsequent stock returns, that is, high prices are followed by low returns, and vice versa. For example, Cochrane (2011) presents a similar figure comparing the log price-dividend ratio and subsequent returns. We establish this pattern for currencies.

Our present-value model allows us to disentangle the movements in the real exchange rate that are due to the interest rate differential and the missing risk premium. We take the model to the data and recover the dynamics of the latent missing risk premium from the restrictions imposed by the model. We use a Kalman filter to estimate it by means of maximum likelihood. We find that the missing risk premium, not the interest rate differential, accounts for most of the variation in the real exchange rate and currency returns. As a result, the missing risk premium is highly correlated with the real exchange rate, in line with our observation that the real exchange rate should predict currency returns.

The model allows us to shed light on the puzzling relation between exchange rates and interest rate differentials [see Frankel and Rose (1995), for a review]. If the currency risk premium depends on the interest rate differential, the present-value model implies that both expected future interest rate differentials and future currency risk premiums depend on interest rate differentials. In the absence of a missing risk premium, we would therefore expect a nearperfect correlation between real exchange rates and interest rate differentials. However, this correlation is weak in the data and typically sends conflicting signals: an increase in the interest rate differential today predicts a higher future return, but that tends to come with a higher current exchange rate, which predicts a lower future return. As the interest rate differential is less persistent than the missing risk premium, it has only a modest effect on the real exchange rate, which is mostly driven by movements in the missing risk premium. Allowing for a missing risk premium resolves this tension.

We highlight the role of the real exchange rate in generating the predictability reversal shown by Bacchetta and Van Wincoop (2010) and Engel (2016). In the data, the positive relation between the currency risk premium and the interest rate differential reverses over the horizon, implying that currencies with higher interest rates appear safer in the long run. Our findings help in understanding this result. We find that the interest rate differential and the missing risk premium have opposite effects. A positive interest rate differential shock raises future returns but also comes with an immediate increase in the missing risk premium. The net effect is an increase in the currency risk premium in the short run. However, as the missing risk premium is more persistent than the interest rate differential, this leads to a decrease in the currency risk premium in the long run. Hence, the currency appears riskier in the short run and safer in the long run, as noted by Engel (2016).

We consider alternative versions of the present-value model to evaluate the robustness of our results. First, we extend our present-value model to allow for additional predictors of currency returns. Recent examples of other predictors include volatility and variance risk premiums (Londono and Zhou, 2017) and external imbalances (Gourinchas and Rey, 2007; Della Corte et al., 2012). Our results remain similar when estimating variants of our model incorporating additional predictors. The additional predictors are less persistent than the real exchange rate and can thus only cast light on currency risk premium fluctuations over short and medium-term horizons. Furthermore, we find that additional predictors do not deliver the strongly negative correlation between interest rate and the missing risk premium, and thus cannot alone reproduce Engel's (2016) predictability reversal.

Second, we evaluate the robustness of our results to alternative assumptions about the dynamics of the real interest rate differential. In our baseline model, we assume that the inflation differential is nonpersistent, such that the movements in real and nominal expected interest rate differentials coincide. We consider alternative assumptions in which the inflation differential is persistent and the real interest rates follow unobserved processes, as in Schorfheide et al. (2018). These alternative dynamics leave our results unchanged.

Third, we entertain the possibility that the real exchange rate is nonstationary. Taken literally, real exchange nonstationarity implies that PPP does not hold. While this appears economically unlikely, nonstationarity is 
notoriously difficult to reject empirically. A looser interpretation is that PPP does hold, but that quasipermanent shocks make the real exchange rate appear nonstationary in short samples. Indeed, in earlier work, Campbell and Clarida (1987) find that shocks to fundamentals accounted for much of the variability in real exchange rates over the 1979-1986 period, when the real exchange rate exhibited trend-like behavior. They relax the assumption that the expected long-run exchange rate is constant, while maintaining that the currency risk premium is proportional to the interest rate differential. We instead consider a model with both a missing risk premium and a time-varying expected long-run exchange rate, and find that variation in the expected long-run exchange rate explains only a modest fraction of real exchange rate movements. To further sharpen our estimates of the expected long-run exchange rate, we link the expected long-run exchange rate to macroeconomic fundamentals. Motivated by Menkhoff et al. (2017), we consider three proxies for fundamentals, differences in country productivity, export quality, and net foreign assets, and our results remain qualitatively the same.

This paper relates to the literature studying currency return predictability beyond the interest rate differential [see Rossi, 2013 for a survey]. In particular, Jordà and Taylor (2012), Boudoukh et al. (2016), and Balduzzi and Chiang (2020) use the real exchange rate to predict currency returns. We contribute by using a present-value model to show why the real exchange rate together with the interest rate differential should predict currency returns. Kremens and Martin (2019) use almost model-free restrictions to construct a measure of the currency risk premium based on quanto prices. Over the short 2009-2017 period for which liquid option prices are available, they find that both their quanto-implied risk premium and the real exchange rate predict currency returns. Chernov and Creal (2021) incorporate PPP into a no-arbitrage model of the stochastic discount factor, the nominal exchange rate, and domestic and foreign nominal yields. They find that the variance of the stochastic discount factor is linked to the real exchange rate, in line with our finding that the currency risk premium is related to the real exchange rate. Most closely related to our paper is Menkhoff et al. (2017), who use a present-value model to justify why the real exchange rate should be used as a value signal in the crosssection. Menkhoff et al. (2017) also consider the possibility that the expected long-run exchange rate could vary over time, which motivates the use of macroeconomic variables to proxy for it. We make the related argument that the real exchange rate should predict currency returns in the time series, and use macroeconomic variables to pin down the expected long-run exchange rate.

This paper also relates to studies that use presentvalue models to decompose stock market movements. The idea of jointly considering return predictability and cash flow predictability is common in studies of the behavior of the aggregate stock market (Campbell and Shiller, 1988; Cochrane, 2011). Our paper draws on the work of Binsbergen and Koijen (2010), who use the Kalman filter to extract expected dividend growth rates and expected stock returns in a present-value model. They find that the expected stock return and the expected dividend growth rate are both persistent, but that the expected stock return is much more persistent than the expected dividend growth rate. Unlike dividend growth rates, interest rate differentials are quite persistent and well approximated by a simple autoregressive process. Another difference from stock markets is that the interest rate differential also tends to predict future currency returns. We nevertheless find that the missing risk premium is more persistent than the interest rate differential. In this dimension, the similarity between the persistence in the real exchange rate (for studying currency returns) and in the price-dividend ratio (for studying stock returns) is striking. Put differently, highly persistent risk premiums can explain movements in the real exchange rate and the price-dividend ratio.

The remainder of this paper proceeds as follows. In Section 2, we present a present-value model with a missing risk premium that can resolve empirical tensions between the interest rate differential and the real exchange rate. In Section 3, we introduce the data and provide predictability regressions as suggested by the present-value model. In Section 4, we estimate our baseline presentvalue model, characterize the currency risk premium, and evaluate the model's ability to reproduce puzzling exchange rate facts. In Section 5, we estimate several alternative present-value models and consider alternative real interest rate dynamics. In Section 6, we offer conclusions. An Online Appendix provides supporting details.

\section{Present-value model}

\subsection{Currency returns and the real exchange rate}

Consider a strategy that borrows in dollars and invests in a foreign currency. The log excess return on this strategy is the dollar depreciation rate plus the interest rate differential:

$r x_{t+1}=s_{t+1}-s_{t}+i_{t}^{*}-i_{t}$,

where $s_{t}$ is the log nominal exchange rate in dollars per unit of foreign currency at date $t$, and $i_{t}$ and $i_{t}^{*}$ are the U.S. and foreign nominal interest rates between dates $t$ and $t+$ 1 , respectively. We refer to $r x_{t+1}$ as a currency return and the conditional expectation of it, $\mathrm{E}_{t}\left(r x_{t+1}\right)$, as the expected currency return or currency risk premium.

Express the return in Eq. (1) in terms of the real depreciation rate and the real interest rate differential:

$r x_{t+1}=q_{t+1}-q_{t}+\left(i_{t}^{*}-\pi_{t+1}^{*}\right)-\left(i_{t}-\pi_{t+1}\right)$,

where $q_{t}=s_{t}+p_{t}^{*}-p_{t}$ is the log real exchange rate, with $p_{t}$ and $p_{t}^{*}$ being the U.S. and foreign log price levels, respectively, and $\pi_{t+1}=p_{t+1}-p_{t}$ and $\pi_{t+1}^{*}=p_{t+1}^{*}-$ $p_{t}^{*}$ being the U.S. and foreign inflation rates, respectively. Rewrite Eq. (2) in terms of the real exchange rate, iterate forward, and take conditional expectations as in Campbell and Clarida (1987) and others:

$$
\begin{aligned}
q_{t}-\omega_{t}= & \sum_{j=1}^{\infty} \mathrm{E}_{t}\left(i_{t+j-1}^{*}-i_{t+j-1}\right)-\sum_{j=1}^{\infty} \mathrm{E}_{t}\left(\pi_{t+j}^{*}-\pi_{t+j}\right) \\
& -\sum_{j=1}^{\infty} \mathrm{E}_{t}\left(r x_{t+j}\right)
\end{aligned}
$$


where $\omega_{t}=\lim _{j \rightarrow \infty} \mathrm{E}_{t}\left(q_{t+j}\right)$. Following Campbell and Clarida (1987), we assume that this limit exists and refer to it as the expected long-run exchange rate. Expression (3) says that the real exchange rate adjusted for its expected long-run level equals the sum of expected future real interest rate differentials (through nominal interest rate differentials and inflation differentials) and the sum of expected future currency returns. Linking to present-value models of stocks, we also refer to the interest rate differentials as cash flows and the expected returns as discount rates.

Absent assumptions as to the time-series properties of the expected long-run exchange rate, nominal interest rate differential, inflation differential, and currency return, expression (3) is essentially without empirical content. Next, we specify the properties of these variables, and consider theoretical and empirical implications of this reduced-form model.

\subsection{Assumptions}

In this subsection, we introduce assumptions needed to operationalize our baseline model. Later, we will consider a number of alternative models in which some of the assumptions are relaxed.

\subsubsection{Currency risk premium}

We begin by specifying the currency risk premium. The empirical results of Fama (1984) and subsequent support in the literature indicate that the nominal interest rate differential predicts currency depreciation. Consider the regression of the future depreciation rate on the current interest rate differential:

$s_{t+1}-s_{t}=\alpha-\beta\left(i_{t}^{*}-i_{t}\right)+\varepsilon_{t+1}$,

where $\varepsilon_{t+1}$ is an error term. UIP states that the nominal exchange rate should, in expectation, depreciate/appreciate corresponding to any difference in interest rates, that is, it implies that $\beta=1$. This is routinely rejected in the data, with estimates of the $\beta$ coefficient being less than one and often negative [see Engel (2014) for a survey]. A negative $\beta$ coefficient means that a currency with a relatively high interest rate tends to appreciate against the dollar, whereas UIP implies that it should instead depreciate against the dollar. This is often referred to as the forward premium puzzle, as it was challenging for earlier models to qualitatively and quantitatively match estimated $\beta$ coefficients. By adding the interest rate differential to both sides of regression (4), we obtain a return-predictability regression:

$r x_{t+1}=\alpha+(1-\beta)\left(i_{t}^{*}-i_{t}\right)+\varepsilon_{t+1}$.

Regressions (4) and (5) are often referred to as Fama regressions.

Fama (1984) remarks that under rational expectations, this regression translates into an expression for the currency risk premium. In addition, when the error term $\varepsilon_{t+1}$ is orthogonal to all available information at date $t$, the regression implies that the interest rate differential is sufficient to pin down the currency risk premium, that is, $\mathrm{E}_{t}\left(r x_{t+1}\right)=\alpha+(1-\beta)\left(i_{t}^{*}-i_{t}\right)$. Several studies have developed asset pricing models that can generate a time-varying currency risk premium. In fact, it is common to choose model parameters such that the currency risk premium is perfectly correlated with the interest rate differential (see, e.g., Backus et al., 2001; Verdelhan, 2010; Farhi and Gabaix, 2016).

In this paper, we assume the following form for the currency risk premium:

$\mathrm{E}_{t}\left(r x_{t+1}\right)=\alpha+(1-\beta)\left(i_{t}^{*}-i_{t}\right)+\gamma y_{t}+\eta_{t}$.

This expression implies that the currency risk premium is not spanned by the interest rate differential, but instead depends on two other variables. The observed variable $y_{t}$ is an additional predictor of currency returns that, under rational expectations, enters the currency risk premium, similar to the interest rate differential. We later discuss candidates for this additional predictor. The latent variable $\eta_{t}$ reflects the potentially missing component of the currency risk premium; we refer to it as the missing risk premium. Importantly, the interest rate differential, additional predictor, and missing risk premium are allowed to correlate with one another.

We view this as a rich reduced-form model of the risk premium. This approach is motivated by Binsbergen and Koijen (2010), who treat the expected stock return as a latent variable in a present-value model of the pricedividend ratio. As it is well-established that the interest rate differentials and other variables have predictive power for currency returns, we consider these variables separately. Note that while the missing risk premium component is unobserved, the present-value model imposes tight restrictions on its properties. The missing risk premium will help us understand the relation between the interest rate differential and the real exchange rate, and will itself be closely related to the real exchange rate.

\subsubsection{Dynamics}

We close the present-value model using additional assumptions as to the dynamics of the model variables. The real exchange rate depends on the expected long-run exchange rate, expected nominal interest rate differential, expected inflation differential, and currency risk premium, which in turn depends on the nominal interest rate, an additional predictor, and the missing risk premium. We discuss each variable in turn.

First, we assume that the real interest rate differential is given by an $\operatorname{AR}(1)$ process for the nominal interest rate differential and a nonpersistent inflation differential:

$i_{t+1}^{*}-i_{t+1}=\left(1-\rho_{i}\right) \mu_{i}+\rho_{i}\left(i_{t}^{*}-i_{t}\right)+\varepsilon_{t+1}^{i}$,

$\pi_{t+1}^{*}-\pi_{t+1}=\mu_{\pi}+\varepsilon_{t+1}^{\pi}$,

where the shocks $\varepsilon_{t+1}^{i}$ and $\varepsilon_{t+1}^{\pi}$ are independently and identically distributed (IID) over time (but potentially cross-correlated), and where $-1<\rho_{i}<1$. Taken together, these two equations translate into a model of the real interest rate differential.

Second, we assume that the additional predictor and the missing risk premium follow mean-zero $\mathrm{AR}(1)$ processes: 
$y_{t+1}=\rho_{y} y_{t}+\varepsilon_{t+1}^{y}$,

$\eta_{t+1}=\rho_{\eta} \eta_{t}+\varepsilon_{t+1}^{\eta}$,

where the shocks $\varepsilon_{t+1}^{y}$ and $\varepsilon_{t+1}^{\eta}$ are IID over time (but potentially cross-correlated with other shocks), and where $-1<\rho_{y}<1$ and $-1<\rho_{\eta}<1$. The zero-mean assumption does not entail loss of generality, as a nonzero mean would be incorporated into the constant term $\alpha$.

Third, we assume that PPP holds in the long run, in the sense that the expected long-run exchange rate is constant:

$\omega_{t}=\mu_{\omega}$.

This assumption implies that the real exchange rate is stationary if the currency return and the real interest rate differential are stationary. Stationarity of real exchange rates is often imposed in the literature (see, e.g., Froot and Ramadorai, 2005; Brunnermeier et al., 2009; Engel, 2016; Balduzzi and Chiang, 2020). This assumption plays a role similar to that of the no-bubble assumption in presentvalue models of stocks (see, e.g., Binsbergen and Koijen, 2010; Campbell and Shiller, 1988). While there seems to be some agreement that real exchange rates are stationary for major currencies, their high persistence makes it statistically difficult to distinguish them from nonstationary processes. For this reason, in our empirical work, we either consider estimation methods robust to various persistence properties or complement the analyses by explicitly modeling PPP deviations.

The above dynamics describe a (sparse) vector autoregressive model for the variables in the present-value model. In most of the paper, we work with the simplest model that can help us understand the properties of the currency risk premium, and the relation between interest rates and the real exchange rate. Hence, we assume that PPP holds and that the inflation process is nonpersistent. In addition, we begin by switching off the additional predictor (i.e., $\gamma=0$ ). We later evaluate the robustness of our findings to additional predictors and more general dynamics.

\subsection{Implications}

Taken together, our model assumptions as to the risk premium, the constant expected long-run exchange rate, and the real interest rate differential lead to the following expression for the real exchange rate (see Appendix A):

$q_{t}-\mu_{\omega}=\beta \frac{i_{t}^{*}-i_{t}-\mu_{i}}{1-\rho_{i}}-\frac{\eta_{t}}{1-\rho_{\eta}}$

Comparing expressions (3) and (12), we see that, rather than being correlated with the sum of expected future interest rate differentials minus the sum of future expected returns, the real exchange rate is just correlated with the current nominal interest rate differential and the missing risk premium. This result follows from expected future interest rate differentials and expected future returns both being proportional to the current nominal interest rate differential. The two-variable structure of the currency risk premium implies that the missing risk premium component also drives the level of the real exchange rate. Note that the real exchange rate inherits the properties of the nominal interest rate differential and the missing risk premium, which both follow stationary AR(1) processes. The real exchange rate is thus stationary. In contrast, the properties of the inflation differential imply that the nominal exchange rate is nonstationary. ${ }^{1}$

Our model implies that the traditional returnpredictability regression (5) translates into (see Appendix A):

$$
\begin{aligned}
r x_{t+1}= & \beta \mu_{i}\left(\frac{\rho_{\eta}-\rho_{i}}{1-\rho_{i}}\right)-\mu_{\pi}+\left(1-\beta \frac{\rho_{\eta}-\rho_{i}}{1-\rho_{i}}\right)\left(i_{t}^{*}-i_{t}\right) \\
& +\left(\rho_{\eta}-1\right)\left(q_{t}-\mu_{\omega}\right)+\varepsilon_{t+1}^{r x}
\end{aligned}
$$

where the return shock is a function of the remaining shocks:

$\varepsilon_{t+1}^{r x}=\beta \frac{\varepsilon_{t+1}^{i}}{1-\rho_{i}}-\frac{\varepsilon_{t+1}^{\eta}}{1-\rho_{\eta}}-\varepsilon_{t+1}^{\pi}$.

This suggests that currency return predictions should include not only the interest rate differential but also the real exchange rate. A univariate regression with only the interest rate differential ignores the long-run restriction implied by PPP and can therefore yield biased estimates of the $\beta$ coefficient. The unexpected currency return is a weighted sum of the interest rate differential shock, $\varepsilon_{t+1}^{i}$; the missing risk premium shock, $\varepsilon_{t+1}^{\eta}$; and the inflation differential shock, $\varepsilon_{t+1}^{\pi}$. Note that as the inflation differential is nonpersistent, it does not appear in the real exchange rate in Eq. (12). However, inflation shocks matter in the short run and affect currency returns in Eq. (14).

\section{Data and predictability regressions}

\subsection{Data}

We retrieve monthly spot and one-month forward exchange rates from Barclays Bank International and Reuters (via Datastream) for the period from January 1976 to May 2020. We consider the G10 currencies: the Australian dollar (AUD), Canadian dollar (CAD), euro (EUR), Japanese yen (JPY), Norwegian krona (NOK), New Zealand dollar (NZD), Swedish krona (SEK), Swiss franc (CHF), pound sterling (GBP), and U.S. dollar (USD). We let the USD be the domestic currency and express all exchange rates in USD per unit of the foreign currency. For the CAD, EUR (spliced with the German mark before 1999), JPY, NOK, SEK, CHF, and GBP, the sample begins in January 1976; for the AUD and NZD, data availability requires that the sample start in January $1985 .^{2}$ We construct an equal-weighted portfolio of the seven countries with full coverage and refer to it simply as the "portfolio."

We compute implied one-month interest rate differentials using the covered interest rate parity (CIP): $i_{t}^{*}-i_{t}=$ $s_{t}-f_{t}$, where $s_{t}$ and $f_{t}$ denote the log spot and forward exchange rates, respectively. As significant deviations from

\footnotetext{
1 The nominal exchange rate is $s_{t}=q_{t}+p_{t}-p_{t}^{*}$, which is the sum of the stationary real exchange rate, $q_{t}$, and the random walk, $p_{t}-p_{t}^{*}$. Hence, the nominal exchange rate cannot be stationary.

2 For the JPY up to 1978, we use data obtained from the Financial Times, as in Hsieh (1984).
} 
Table 1

Summary statistics.

This table presents means, standard deviations, and first-order autocorrelations for key variables: $r x_{t}$ is the log excess return for a U.S. investor going long a foreign currency, $q_{t}$ is the demeaned log real exchange rate in USD per unit of foreign currency, $i_{t}^{*}-i_{t}$ is the difference between foreign and U.S. interest rates, and $\pi_{t}^{*}-\pi_{t}$ is the difference between foreign and U.S. inflation rates. All variables are sampled monthly. Results are reported for Australia (AUD), Canada (CAD), Germany (EUR), Japan (JPY), New Zealand (NZD), Norway (NOK), Sweden (SEK), Switzerland (CHF), the UK (GBP), and an equal-weighted average of the seven currencies with full coverage (referred to as the portfolio).

\begin{tabular}{|c|c|c|c|c|c|c|c|c|c|c|c|}
\hline & & AUD & CAD & $\mathrm{CHF}$ & EUR & GBP & JPY & NOK & NZD & SEK & Portfolio \\
\hline \multicolumn{2}{|c|}{ Sample begins: } & 85.01 & 76.02 & 76.02 & 76.02 & 76.02 & 76.02 & 76.02 & 85.01 & 76.02 & 76.02 \\
\hline \multicolumn{2}{|c|}{ Sample ends: } & 20.05 & 20.05 & 20.05 & 20.05 & 20.05 & 20.05 & 20.05 & 20.05 & 20.05 & 20.05 \\
\hline \multirow[t]{3}{*}{$r x_{t}$} & Mean (\%) & 0.178 & -0.005 & -0.045 & -0.043 & 0.032 & -0.038 & 0.055 & 0.376 & -0.030 & -0.011 \\
\hline & S.D. (\%) & 3.413 & 2.029 & 3.383 & 3.090 & 2.960 & 3.246 & 3.085 & 3.574 & 3.134 & 2.343 \\
\hline & $\mathrm{AC}(1)$ & 0.053 & -0.042 & 0.009 & 0.020 & 0.077 & 0.059 & 0.031 & -0.006 & 0.080 & 0.051 \\
\hline \multirow[t]{3}{*}{$q_{t}-\mu_{q}$} & Mean (\%) & 0.000 & 0.000 & 0.000 & 0.000 & 0.000 & 0.000 & 0.000 & 0.000 & 0.000 & 0.000 \\
\hline & S.D. (\%) & 18.238 & 11.947 & 15.723 & 15.460 & 12.736 & 18.991 & 14.501 & 18.874 & 21.009 & 12.320 \\
\hline & $A C(1)$ & 0.982 & 0.981 & 0.976 & 0.979 & 0.969 & 0.982 & 0.972 & 0.972 & 0.984 & 0.980 \\
\hline \multirow[t]{3}{*}{$i_{t}^{*}-i_{t}$} & Mean (\%) & 0.229 & 0.055 & -0.232 & -0.116 & 0.125 & -0.233 & 0.161 & 0.313 & 0.114 & -0.018 \\
\hline & S.D. (\%) & 0.234 & 0.139 & 0.267 & 0.229 & 0.227 & 0.231 & 0.290 & 0.359 & 0.308 & 0.181 \\
\hline & $\mathrm{AC}(1)$ & 0.907 & 0.813 & 0.873 & 0.882 & 0.898 & 0.882 & 0.819 & 0.877 & 0.782 & 0.884 \\
\hline \multirow[t]{3}{*}{$\pi_{t}^{*}-\pi_{t}$} & Mean (\%) & 0.058 & -0.005 & -0.156 & -0.108 & 0.061 & -0.177 & 0.035 & 0.057 & 0.023 & -0.047 \\
\hline & S.D. (\%) & 0.615 & 0.327 & 0.387 & 0.408 & 0.489 & 0.490 & 0.520 & 0.773 & 0.528 & 0.287 \\
\hline & $\mathrm{AC}(1)$ & -0.124 & 0.008 & 0.239 & 0.096 & 0.122 & 0.125 & 0.134 & -0.088 & 0.127 & 0.230 \\
\hline
\end{tabular}

the CIP have been seen since the global financial crisis of 2007-2009 (Du et al., 2018), the implied interest rate differential can be seen as a shadow differential or a differential including convenience yields (Engel and Wu, 2020; Jiang et al., 2021). Log excess returns for a U.S. investor going long a foreign currency are computed as $r x_{t+1}=$ $s_{t+1}-s_{t}+i_{t}^{*}-i_{t}$. Log real exchange rates are computed as $q_{t}=s_{t}+p_{t}^{*}-p_{t}$, where $p_{t}^{*}$ and $p_{t}$ are log consumer price indexes obtained from the Organisation for Economic Cooperation and Development (OECD). Log inflation differentials are computed as $\pi_{t}^{*}-\pi_{t}=\left(p_{t}^{*}-p_{t-1}^{*}\right)-\left(p_{t}-p_{t-1}\right)$. The statistical agencies in Australia and New Zealand release price indexes on a quarterly basis. We therefore forward fill the price indexes for the AUD and NZD in the months until the next quarter. This creates stale prices but avoids introducing future information into the economist's information set.

Table 1 reports summary statistics for monthly returns, real exchange rates, interest rate differentials, and inflation differentials for each currency as well as the portfolio. Returns are on average low, but quite volatile, with monthly standard deviations in the $2.0-3.6 \%$ range. Returns exhibit little serial correlation. The real exchange rates and the interest rate differentials are highly persistent. The firstorder autocorrelations are higher for the real exchange rates $(0.980$ for the portfolio) than for the interest rate differentials ( 0.884 for the portfolio). The autocorrelation of the inflation differential is weakly positive for the currencies with monthly prices and a full sample period, whereas it is weakly negative for the AUD and NZD due to the stale forward-filled monthly prices.

\subsection{Predictability regressions}

We next run predictability regressions of the future currency return on the current interest rate differential and the current real exchange rate:

$r x_{t+1}=a+b\left(i_{t}^{*}-i_{t}\right)+c q_{t}+u_{t+1}$, where the present-value model suggests that

$b=1-\beta \frac{\rho_{\eta}-\rho_{i}}{1-\rho_{i}} \quad$ and $\quad c=\rho_{\eta}-1$.

As it is well known that high persistence in regressors and correlations between regressor innovations and return innovations raise econometric concerns (Stambaugh, 1999), we use the instrumentation procedure developed by Kostakis et al. (2015) in addition to OLS. The procedure is derived from Magdalinos and Phillips (2009) and consists of removing endogeneity by a filtering procedure referred to as IVX estimation. Intuitively, the method controls the degree of persistence of data-filtered IVX instruments. The tests for predictability are robust to various persistence properties (i.e., unit root, local-to-unit root, near stationary, and stationary) of the interest rate differential and the real exchange rate, and can be applied to predictability regressions of multihorizon returns.

Panel A of Table 2 reports regressions of the future currency return on the current interest rate differential only. In the first two columns we report OLS and IVX regressions for the portfolio (the "poor man's" pooling). We complement these regressions with a panel regression of all nine currencies, allowing for fixed currency effects. The estimates of $b$ are all above one and significantly different from zero, in contrast to the UIP prediction $\beta=1$ (i.e., $b=$ 0 ), where the interest rate differential on average equals the currency depreciation.

We argue that the Fama regression can contain an omitted-variable bias once one recognizes the implications of our present-value model. Panel B of Table 2 reports regressions in which we include the real exchange rate as in regression (15). In principle, correcting for the omittedvariable bias could restore the UIP prediction $\beta=1$. However, we now find more positive estimates of the $b$ coefficients (i.e., stronger evidence that interest rate differentials negatively predict future exchange rate depreciations). When the real exchange rate is high (i.e., the foreign 
Table 2

Predicting currency returns.

Panel A presents predictive regressions of the future currency return, $r x_{t+1}$, on the current interest rate differential, $i_{t}^{*}-i_{t}$, and the current real exchange rate, $q_{t}$. Panel B presents predictive regressions of one-year cumulative returns, $r x_{t, t+12}=\sum_{k=1}^{12} r x_{t+k}$, on the same variables. One-month-horizon OLS regressions for the currency portfolio are reported with Newey and West (1987) standard errors, accounting for conditional heteroskedasticity and serial correlation up to three lags, in parentheses. One-year-horizon OLS regressions are reported with Hansen and Hodrick (1980) corrected standard errors with 12 lags. The IVX column shows results using the instrumentation procedure developed by Kostakis et al. (2015), in which $p$-values are computed according to a Wald test of significance for each individual predictor. The panel regressions consider unbalanced data on nine currencies versus the dollar and use moment conditions as in Bansal and Dahlquist (2000). They include currency fixed effects and standard errors allow for cross-sectional and serial correlation in the errors as well as for heteroskedasticity in the errors. The one-year panel regression is reported for both nonoverlapping observations (returns are over a calendar year) and overlapping observations. The $R^{2}$ values for the panel regressions are within- $R^{2}$ values. ${ }^{* * *} p<0.01,{ }^{* *} p<0.05,{ }^{*} p<0.10$

\begin{tabular}{|c|c|c|c|c|}
\hline & OLS & IVX & Panel (nonoverlapping) & Panel (overlapping) \\
\hline \multicolumn{5}{|c|}{ Panel A: One-month horizon } \\
\hline \multicolumn{5}{|c|}{$r x_{t+1}=a+b\left(i_{t}^{*}-i_{t}\right)+u_{t+1}$} \\
\hline$b$ & $1.898^{* *}$ & $1.897^{* * *}$ & $1.615^{* * *}$ & \\
\hline (s.e.) & $(0.748)$ & $(0.558)$ & $(0.365)$ & \\
\hline$R^{2}$ & 0.022 & 0.022 & 0.018 & \\
\hline $\mathrm{N}$ & 531 & 531 & 4,574 & \\
\hline \multicolumn{5}{|c|}{$r x_{t+1}=a+b\left(i_{t}^{*}-i_{t}\right)+c q_{t}+u_{t+1}$} \\
\hline$b$ & $2.158^{* * *}$ & $2.090^{* * *}$ & $1.777^{* * *}$ & \\
\hline (s.e.) & $(0.729)$ & $(0.582)$ & $(0.364)$ & \\
\hline c & $-0.016^{*}$ & $-0.014^{*}$ & $-0.017^{* * *}$ & \\
\hline (s.e.) & $(0.009)$ & $(0.008)$ & $(0.006)$ & \\
\hline$R^{2}$ & 0.028 & 0.026 & 0.026 & \\
\hline $\mathrm{N}$ & 531 & 531 & 4,574 & \\
\hline \multicolumn{5}{|c|}{ Panel B: One-year horizon } \\
\hline \multicolumn{5}{|c|}{$r x_{t, t+12}=a+b\left(i_{t}^{*}-i_{t}\right)+u_{t, t+12}$} \\
\hline$b$ & $19.583^{* * *}$ & $19.825^{* * *}$ & $16.272^{* * *}$ & $14.405^{* * *}$ \\
\hline (s.e.) & $(6.487)$ & $(5.908)$ & (3.591) & (3.240) \\
\hline$R^{2}$ & 0.140 & 0.144 & 0.132 & 0.095 \\
\hline $\mathrm{N}$ & 520 & 520 & 371 & 4,466 \\
\hline \multicolumn{5}{|c|}{$r x_{t, t+12}=a+b\left(i_{t}^{*}-i_{t}\right)+c q_{t}+u_{t, t+12}$} \\
\hline $\begin{array}{l}b \\
\text { (s.e.) }\end{array}$ & $\begin{array}{l}23.301^{* * *} \\
(6.236)\end{array}$ & $\begin{array}{l}22.686^{* * *} \\
(6.150)\end{array}$ & $\begin{array}{l}17.897^{* * * *} \\
(3.214)\end{array}$ & $\begin{array}{l}16.514^{* * *} \\
(3.085)\end{array}$ \\
\hline$c$ & $-0.252^{* *}$ & $-0.232^{* *}$ & $-0.247^{* * *}$ & $-0.244^{* * *}$ \\
\hline (s.e.) & $(0.102)$ & $(0.100)$ & $(0.067)$ & $(0.064)$ \\
\hline$R^{2}$ & 0.237 & 0.218 & 0.244 & 0.202 \\
\hline $\mathrm{N}$ & 520 & 520 & 371 & 4,466 \\
\hline
\end{tabular}

currency is expensive relative to the dollar), future currency returns tend to be lower. A one-standard-deviation increase in the real exchange rate lowers the next-month return by $0.20 \%$. This effect is similar to that of a onestandard-deviation change in the interest rate differential. While the point estimates are large, they are imprecise and one could worry about the statistical significance. Note, however, that a more powerful null hypothesis would condition on a stationary real exchange rate. Cochrane (2008) makes this point in the context of predicting stock market returns using the price-dividend ratio. If the price-dividend ratio is stationary, it must predict future dividend growth, future returns, or both. Likewise, if the real exchange rate is stationary, it must predict future interest rate differentials, future returns, or both. Balduzzi and Chiang (2020) apply this idea to exchange rates and reject the null hypothesis that the real exchange rate does not predict currency returns.

A large literature shows that PPP holds better over long horizons (e.g., Mark, 1995; Eichenbaum et al., 2021), which should translate into stronger predictive power of the real exchange rate in long-horizon regressions. Panels $C$ and $D$ of Table 2 report results of the predictive regression of one-year returns. The OLS and IVX estimates are statistically significant at the $5 \%$ level. This is consistent with Boudoukh et al. (2016), who use the real exchange rate as a predictor of exchange rate depreciation over the oneyear horizon. Complementing panel regressions (both with and without overlapping observations) confirm the predictive power of the interest rate differential and the real exchange rate. We further illustrate this point in Fig. 1, which plots the real exchange rate against subsequent five-year currency returns. They are highly negatively correlated, suggesting that future currency returns offset changes in the real exchange rate.

We evaluate whether our predictability results are similar across currencies. For example, one concern could be that safe-haven currencies like CHF and JPY behave differently from other major currencies. Table 3 reports OLS results for the individual currencies (the Online Appendix 
Table 3

Predicting individual currency returns.

Panel A presents predictive regressions of the future currency return, $r x_{t+1}$, on the current interest rate differential, $i_{t}^{*}-i_{t}$, and the current real exchange rate, $q_{t}$. Panel B presents predictive regressions of one-year cumulative returns, $r x_{t, t+12}=\sum_{k=1}^{12} r x_{t+k}$, on the same variables. One-month-horizon OLS regressions for the currency portfolio are reported with Newey and West (1987) standard errors, accounting for conditional heteroskedasticity and serial correlation up to three lags, in parentheses. One-year-horizon OLS regressions are reported with Hansen and Hodrick (1980) corrected standard errors with 12 lags. ${ }^{* * *} p<0.01,{ }^{* *} p<0.05,{ }^{*} p<0.10$.

\begin{tabular}{|c|c|c|c|c|c|c|c|c|c|}
\hline & AUD & CAD & $\mathrm{CHF}$ & EUR & GBP & JPY & NOK & NZD & SEK \\
\hline \multicolumn{10}{|c|}{ Panel A: One-month horizon } \\
\hline \multicolumn{10}{|c|}{$r_{t+1}=a+b\left(i_{t}^{*}-i_{t}\right)+u_{t+1}$} \\
\hline$b$ & $1.921^{* * *}$ & $1.797^{* * * *}$ & $1.771^{* *}$ & $1.527^{* *}$ & $2.305^{* * *}$ & $2.494^{* * *}$ & $1.105^{*}$ & $1.982^{* * *}$ & 0.555 \\
\hline (s.e.) & $(0.593)$ & $(0.530)$ & $(0.709)$ & $(0.763)$ & $(0.730)$ & $(0.595)$ & $(0.661)$ & $(0.444)$ & $(0.699)$ \\
\hline$R^{2}$ & 0.017 & 0.015 & 0.019 & 0.013 & 0.031 & 0.031 & 0.011 & 0.040 & 0.003 \\
\hline $\mathrm{N}$ & 425 & 531 & 531 & 531 & 531 & 531 & 531 & 425 & 531 \\
\hline \multicolumn{10}{|c|}{$r_{t+1}=a+b\left(i_{t}^{*}-i_{t}\right)+c q_{t}+u_{t+1}$} \\
\hline$b$ & $2.053^{* * *}$ & $2.494^{* * *}$ & $2.291^{* * *}$ & $1.727^{* *}$ & $2.468^{* * *}$ & $2.470^{* * *}$ & $1.199^{*}$ & $1.762^{* * *}$ & 0.859 \\
\hline (s.e.) & $(0.608)$ & $(0.647)$ & $(0.741)$ & $(0.759)$ & $(0.734)$ & $(0.594)$ & $(0.651)$ & $(0.444)$ & $(0.786)$ \\
\hline$c$ & $-0.016^{*}$ & $-0.022^{* * *}$ & $-0.028^{* *}$ & $-0.018^{*}$ & $-0.024^{*}$ & -0.013 & -0.014 & $-0.017^{*}$ & -0.009 \\
\hline (s.e.) & $(0.009)$ & $(0.008)$ & $(0.012)$ & $(0.010)$ & $(0.013)$ & $(0.008)$ & $(0.010)$ & $(0.010)$ & $(0.007)$ \\
\hline$R^{2}$ & 0.024 & 0.029 & 0.035 & 0.020 & 0.041 & 0.037 & 0.015 & 0.047 & 0.006 \\
\hline $\mathrm{N}$ & 425 & 531 & 531 & 531 & 531 & 531 & 531 & 425 & 531 \\
\hline \multicolumn{10}{|c|}{ Panel B: One-year horizon } \\
\hline \multicolumn{10}{|c|}{$r_{t, t+12}=a+b\left(i_{t}^{*}-i_{t}\right)+u_{t, t+12}$} \\
\hline$b$ & $17.427^{* *}$ & 5.797 & $17.284^{* * *}$ & $14.384 * *$ & $16.282^{* * *}$ & $23.896^{* * *}$ & $11.539^{* *}$ & $14.765^{* * *}$ & 8.419 \\
\hline (s.e.) & $(7.923)$ & $(6.109)$ & $(6.121)$ & $(7.074)$ & $(6.153)$ & $(6.824)$ & $(5.020)$ & $(5.286)$ & $(5.229)$ \\
\hline$R^{2}$ & 0.107 & 0.014 & 0.130 & 0.072 & 0.104 & 0.175 & 0.080 & 0.149 & 0.039 \\
\hline $\mathrm{N}$ & 414 & 520 & 520 & 520 & 520 & 520 & 520 & 414 & 520 \\
\hline \multicolumn{10}{|c|}{$r_{t, t+12}=a+b\left(i_{t}^{*}-i_{t}\right)+c q_{t}+u_{t, t+12}$} \\
\hline$b$ & $19.158^{* *}$ & $11.677^{*}$ & $23.764^{* * *}$ & $17.336^{* * *}$ & $18.041^{* * *}$ & $23.580^{* * *}$ & $12.755^{* * *}$ & $11.203^{* *}$ & $14.540^{* * * *}$ \\
\hline (s.e.) & $(7.479)$ & $(6.035)$ & $(5.688)$ & $(6.704)$ & $(5.605)$ & $(6.455)$ & $(4.877)$ & $(5.020)$ & $(5.335)$ \\
\hline$c$ & $-0.217^{* *}$ & $-0.188^{* *}$ & $-0.350^{* * *}$ & $-0.272^{* *}$ & $-0.363^{* * *}$ & $-0.208^{* *}$ & $-0.220^{*}$ & $-0.262^{* * *}$ & $-0.204^{* *}$ \\
\hline (s.e.) & $(0.098)$ & $(0.085)$ & $(0.102)$ & $(0.106)$ & $(0.112)$ & $(0.088)$ & $(0.114)$ & $(0.100)$ & $(0.096)$ \\
\hline$R^{2}$ & 0.210 & 0.104 & 0.297 & 0.185 & 0.257 & 0.263 & 0.146 & 0.275 & 0.118 \\
\hline $\mathrm{N}$ & 414 & 520 & 520 & 520 & 520 & 520 & 520 & 414 & 520 \\
\hline
\end{tabular}

reports the corresponding IVX results). Although point estimates are less precisely estimated, we find that they are similar across currencies. This lends support to the generality of our findings and that pooling of currencies is reasonable.

Overall, the evidence in this subsection indicates that the real exchange rate has predictive power for currency returns. While this is already known, we contribute by introducing a latent risk premium component in a presentvalue model that suggests that the real exchange rate should be included in the predictability regression. Note that this does not mean that the real exchange rate is the missing risk premium. The real exchange rate also contains information about future interest rate differentials and thus only imperfectly captures the risk premium. Furthermore, the real exchange rate could vary because the expected long-run exchange rate varies over time (i.e., the real exchange rate is nonstationary). Finally, our assumption about the risk premium could neglect other variables that have predictive power for currency returns. As these issues are better addressed within the present-value framework, we return to them in Section 5.

\section{Taking the model to the data}

In this section, we estimate our present-value model and study its implications. Our model assumes that the real exchange rate is a function of both an observable variable (i.e., the nominal interest rate differential) and an unobserved variable (i.e., the missing risk premium). This dif- fers from related studies of the stock market, which typically feature two unobserved variables. A key aspect of currencies is that the cash flows that accrue to investors are future interest rate differentials. Interest rate differentials are highly persistent, which means that the current interest rate differential captures expected future interest rate differentials. This is different from stocks. Like the log real exchange rate, valuation ratios such as the log pricedividend ratio approximately equal the present value of future cash flows minus expected stock returns. However, future cash flows are much harder to predict, which means that the model has to accommodate a second unobserved variable. The presence of two unobserved variables motivates the Kalman filtering approach of Binsbergen and Koijen (2010). Our models do not require this complication. However, this additional degree of freedom lets us later explore models featuring an additional unobserved variable: the expected long-run exchange rate, as in Campbell and Clarida (1987).

\subsection{Model estimation}

We can cast our model in the following state-space form:

$Y_{t}=A X_{t}+v_{t}$

$X_{t}=B X_{t-1}+\varepsilon_{t}$,

where $A$ and $B$ are matrices of the underlying parameters of the present-value model. To reduce the number of pa- 


\section{Table 4}

Estimation of the baseline model.

This table presents estimates of the present-value model with a constant expected long-run exchange rate (stationary model). Expressions for the model are given in Appendix B. The model is estimated by maximum likelihood for the currency portfolio. Standard errors are reported in parentheses.

\begin{tabular}{cc}
\hline$\beta$ & -1.764 \\
(s.e.) & $(0.654)$ \\
$\rho_{i}$ & 0.882 \\
(s.e.) & $(0.014)$ \\
$\sigma_{i}$ & 0.085 \\
(s.e.) & $(0.001)$ \\
$\rho_{\eta}$ & 0.978 \\
$($ s.e. & $(0.008)$ \\
$\sigma_{\eta}$ & 0.062 \\
(s.e.) & $(0.025)$ \\
$\rho_{\eta i}$ & -0.611 \\
(s.e.) & $(0.118)$ \\
Log-likelihood & -631.6 \\
\hline
\end{tabular}

rameters to be estimated, we work with demeaned variables. Eq. (17) is the measurement equation, where $Y_{t}$ is a vector of observed variables; Eq. (18) is the transition equation for the state vector $X_{t}$, which includes variables that are potentially unobserved. Finally, $v_{t}$ and $\varepsilon_{t}$ are vectors of observation errors and state innovations, respectively, that are IID over time but potentially correlated. Since all equations are affine, under the extra assumption that the shocks are normally distributed, we can use the Kalman filter and estimate the model with maximum likelihood (Hamilton, 1994).

The measurement equation consists of the real exchange rate and the interest rate differential, $Y_{t}=\left[q_{t}, i_{t}^{*}-\right.$ $\left.i_{t}\right]$, and the state vector contains the interest rate differential and the missing risk premium, $X_{t}=\left[i_{t}^{*}-i_{t}, \eta_{t}\right]$. The measurement equation for the real exchange rate is given by Eq. (12); the dynamics of the state vector are given by Eqs. (7) and (10). Note that there is no error term in the measurement equations, which allows us to model the comovements between the missing risk premium and the interest rate differential in the vector $\varepsilon_{t}=\left[\varepsilon_{t}^{i}, \varepsilon_{t}^{\eta}\right]$. In sum, we have the following state-space system:

$$
\begin{aligned}
& {\left[\begin{array}{c}
q_{t} \\
i_{t}^{*}-i_{t}
\end{array}\right]=\left[\begin{array}{cc}
\frac{\beta}{1-\rho_{i}} & \frac{-1}{1-\rho_{\eta}} \\
1 & 0
\end{array}\right]\left[\begin{array}{c}
i_{t}^{*}-i_{t} \\
\eta_{t}
\end{array}\right],} \\
& {\left[\begin{array}{c}
i_{t}^{*}-i_{t} \\
\eta_{t}
\end{array}\right]=\left[\begin{array}{cc}
\rho_{i} & 0 \\
0 & \rho_{\eta}
\end{array}\right]\left[\begin{array}{c}
i_{t-1}^{*}-i_{t-1} \\
\eta_{t-1}
\end{array}\right]+\left[\begin{array}{c}
\varepsilon_{t}^{i} \\
\varepsilon_{t}^{\eta}
\end{array}\right],}
\end{aligned}
$$

with

$\operatorname{Var}\left(\left[\begin{array}{c}\varepsilon_{t}^{i} \\ \varepsilon_{t}^{\eta}\end{array}\right]\right)=\left[\begin{array}{ll}\sigma_{i}^{2} & \sigma_{\eta i} \\ \sigma_{\eta i} & \sigma_{\eta}^{2}\end{array}\right]$.

The corresponding correlation between the shocks in Eq. (21) is denoted $\rho_{\eta i}$. Our baseline model then comprises six parameters in total: $\rho_{i}, \sigma_{i}, \beta, \rho_{\eta}, \sigma_{\eta}$, and $\rho_{\eta i}$.

\subsection{Estimation results}

Table 4 presents estimates of the model parameters for the currency portfolio. We found earlier, in line with

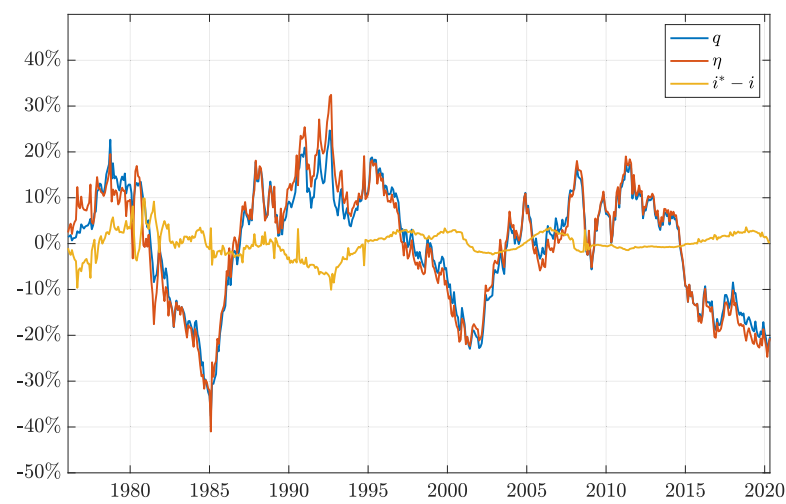

Fig. 2. Real exchange rate decomposition. This figure shows the decomposition of the level of the log real exchange rate $\left(q_{t}\right.$, in blue), according to Eq. (12), into the missing risk premium ( $\eta_{t}$, in red) and interest rate differential $\left(i_{t}^{*}-i_{t}\right.$, in yellow) components. (For interpretation of the references to color in this figure legend, the reader is referred to the web version of this article.)

the literature, that the implied $\beta$ coefficients in the Fama regressions are mostly negative, indicating that highinterest-rate currencies tend to have higher future returns. Table 4 reports $\beta$ estimates that are even more negative than implied by the coefficients in Table 2 .

Next, consider the estimates of the volatility and persistence parameters. While the interest rate differential shock is more volatile than the missing risk premium shock (i.e., $\sigma_{i}>\sigma_{\eta}$ ), the missing risk premium is more persistent than the interest rate differential (i.e., $\rho_{\eta}>\rho_{i}$ ). This difference in persistence is economically large and significant. The estimate of $\rho_{i}$ is 0.882 , corresponding to a half-life of about 5.5 months for the average interest rate differential. The estimate of $\rho_{\eta}$ is 0.978 , corresponding to a halflife of 31.7 months for the missing risk premium, which is broadly consistent with previous estimates of deviations from PPP (see, e.g., Rogoff, 1996; Burstein and Gopinath, 2014). Importantly, the missing risk premium shock and the interest rate differential shock are negatively correlated $(-0.611)$. Later we show that this correlation coefficient allows the comovement between the real exchange rate and the interest rate differential to be consistent with the data.

We report individual currency results in the Online Appendix. While there is heterogeneity in the parameter estimates, they convey the same message. For example, the $\beta$ estimates are all negative, in the range from -0.4 to -2.6 . For each currency, we observe that the volatility of the interest rate differential shock is greater than the volatility of the missing risk premium shock and that the missing risk premium is more persistent than the interest rate differential. These results are in line with the results for the currency portfolio.

\subsection{Decompositions}

Fig. 2 shows decompositions of the real exchange rate according to Eq. (12). Most of the variation in the real exchange rate is captured by the missing risk premium. The figure also reproduces the disconnect between the real ex- 


\section{Table 5}

Variance decomposition of the unexpected currency return.

This table presents variance decompositions of the unexpected currency return (with standard errors in parentheses):

$$
1=\frac{\operatorname{Cov}\left(\frac{\varepsilon_{t+1}^{i}}{1-\rho_{i}}, \varepsilon_{t+1}^{r x}\right)}{\operatorname{Var}\left(\varepsilon_{t+1}^{r x}\right)}+\frac{\operatorname{Cov}\left(-\varepsilon_{t+1}^{\pi}, \varepsilon_{t+1}^{r x}\right)}{\operatorname{Var}\left(\varepsilon_{t+1}^{r x}\right)}+\frac{\operatorname{Cov}\left((\beta-1) \frac{\varepsilon_{t+1}^{i}}{1-\rho_{i}}, \varepsilon_{t+1}^{r x}\right)}{\operatorname{Var}\left(\varepsilon_{t+1}^{r x}\right)}+\frac{\operatorname{Cov}\left(\frac{\varepsilon_{t+1}^{\eta}}{1-\rho_{\eta}}, \varepsilon_{t+1}^{r x}\right)}{\operatorname{Var}\left(\varepsilon_{t+1}^{r x}\right)}+\frac{\operatorname{Cov}\left(\varepsilon_{t+1}^{\omega}, \varepsilon_{t+1}^{r x}\right)}{\operatorname{Var}\left(\varepsilon_{t+1}^{r x}\right)}+\frac{\operatorname{Cov}\left(\frac{\varepsilon_{t+1}^{y}}{1-\rho_{y}}, \varepsilon_{t+1}^{r x}\right)}{\operatorname{Var}\left(\varepsilon_{t+1}^{r x}\right)} \text {. }
$$

The baseline present-value model makes a contribution due to the interest rate differential shock $\left(\varepsilon^{i}\right)$, split into a cash flow component $\left(\varepsilon_{C F}^{i}\right)$ and a risk premium component $\left(\varepsilon_{R P}^{i}\right)$, the missing risk premium shock $\left(\varepsilon^{\eta}\right)$, and the inflation differential shock $\left(\varepsilon^{\pi}\right)$. NXA, XVP, and VRP refer to the deviation from trend of a weighted combination of: gross assets, gross liabilities, gross exports, and gross imports; the global currency variance risk premium; and the equity variance risk premium, respectively. The column labeled "Real model" reports the decomposition for the alternative modeling of the real interest rate differential (index $i$ here refers to the real interest rate differential). The models with additional predictors also make a contribution due to the shock in a predictor ( $\varepsilon^{y}$ ). The models with expected long-run exchange rate also make a contribution due to their shock $\left(\varepsilon^{\omega}\right)$. Prod, Qual, and NFA refer to productivity, quality, and net foreign assets, respectively (see Table 9). Standard errors are based on the delta method.

\begin{tabular}{|c|c|c|c|c|c|c|c|c|c|}
\hline & \multirow[t]{2}{*}{$\begin{array}{l}\text { Baseline } \\
\text { model }\end{array}$} & \multicolumn{3}{|c|}{ Additional predictor models } & \multirow[t]{2}{*}{$\begin{array}{c}\text { Real } \\
\text { model }\end{array}$} & \multicolumn{4}{|c|}{$\begin{array}{l}\text { Time-varying expected long-run exchange rate } \\
\text { models }\end{array}$} \\
\hline & & NXA & XVP & VRP & & - & Prod & Qual & NFA \\
\hline$\varepsilon_{C F}^{i}$ & 6.4 & 6.5 & 6.6 & 6.3 & 0.4 & 7.4 & 6.4 & 6.3 & 6.3 \\
\hline (s.e.) & $(1.3)$ & $(1.4)$ & $(1.4)$ & $(1.3)$ & $(0.6)$ & $(1.5)$ & $(1.3)$ & $(1.3)$ & $(1.3)$ \\
\hline$\varepsilon_{R P}^{i}$ & -17.6 & -17.4 & -19.9 & -16.6 & -1.6 & -24.5 & -17.7 & -16.7 & -17.3 \\
\hline (s.e.) & $(6.0)$ & $(6.2)$ & $(7.4)$ & $(5.9)$ & $(2.4)$ & $(7.1)$ & $(6.1)$ & $(5.8)$ & $(6.0)$ \\
\hline$\varepsilon^{\eta}$ & 109.7 & 92.7 & 114.9 & 108.5 & 99.7 & 126.7 & 109.7 & 100.4 & 104.8 \\
\hline (s.e.) & $(5.2)$ & $(13.7)$ & $(7.1)$ & $(5.1)$ & (1.9) & $(9.5)$ & $(5.2)$ & $(9.2)$ & $(8.1)$ \\
\hline$\varepsilon^{\pi}$ & 1.5 & 1.5 & 1.5 & 1.5 & & 1.5 & 1.5 & 1.5 & 1.5 \\
\hline (s.e.) & $(0.1)$ & $(0.1)$ & $(0.1)$ & $(0.1)$ & & $(0.1)$ & $(0.1)$ & $(0.1)$ & $(0.1)$ \\
\hline$\varepsilon^{y}$ & & 16.7 & -3.1 & 0.3 & & & & & \\
\hline (s.e.) & & (13.0) & $(2.7)$ & (1.0) & & & & & \\
\hline$\varepsilon^{\omega}$ & & & & & & -11.0 & 0.0 & 8.4 & 4.6 \\
\hline (s.e.) & & & & & & (4.1) & $(0.4)$ & $(8.0)$ & (6.1) \\
\hline
\end{tabular}

change rate and the interest rate differential. Although the interest rate differential captures currency risk premium movements over short horizons, its effect dies out when accumulated to the exchange rate level (i.e., to an infinite horizon). The Online Appendix shows real exchange rate decompositions for individual currencies, as Fig. 2 does. Again, the real exchange rate variations are mainly due to movements in the missing risk premium.

Next, we ask what fraction of the unexpected currency return can be attributed to each component. Table 5 presents estimates for the variance decomposition of the unexpected currency return. The first column reports the results for the baseline model with unexpected return, (14). The remaining columns report the results for models with additional predictors, a model with the real interest rate differential, and models with a time-varying expected long-run exchange rate (discussed later). We compute decompositions for the currency return rather than the real exchange rate, as the return is stationary even if the real exchange rate is nonstationary. We decompose the currency return into cash flow and discount rate shocks and thus split the variance attributable to interest rate shocks into a cash flow component and a discount rate component.

Table 5 shows that cash flow shocks (due to interest rate and inflation shocks) account for around $8 \%$ of the variance of unexpected returns. Discount rates account for around $92 \%$ of the variance of unexpected returns. This result is expected: there is mounting evidence that discount rate shocks dominate asset price movements (Cochrane, 2011). Balduzzi and Chiang (2020) find similar reduced-form evidence for the real exchange rate under stationarity.

\subsection{Properties of the currency risk premium}

In this subsection, we discuss the implications of a missing risk premium for the properties of the currency risk premium. Fama (1984) remarks that the slope coefficient $\beta$ in regression (4) has implications for the expected depreciation rate, $\mathrm{E}_{t}\left(\Delta s_{t+1}\right)$, as well as for the risk premium, $\mathrm{E}_{t}\left(r x_{t+1}\right)$. UIP implies that $\beta=1$ and that the currency risk premium is zero, that is, $\mathrm{E}_{t}\left(r x_{t+1}\right)=0$, whereas when $\beta \neq 1$, the currency risk premium is time varying. ${ }^{3}$ Furthermore, the $\beta$ coefficient reveals conditions of how much the risk premium varies in comparison with the expected depreciation rate (a variance condition), and how the risk premium and the expected depreciation rate covary (a covariance condition). Satisfying these conditions requires that the price of risk should be high when domestic interest rates are low and foreign interest rates are high, which macro-finance models had difficulty reproducing in the past. While these conditions were originally cast in a regression model in which the currency risk premium was spanned by the interest rate differential, it is useful to evaluate whether they continue to hold in our presentvalue model.

The variance condition is that $\operatorname{Var}\left(\mathrm{E}_{t}\left(r x_{t+1}\right)\right)>$ $\operatorname{Var}\left(\mathrm{E}_{t}\left(\Delta s_{t+1}\right)\right)$. We know from Table 2 that conditioning on the real exchange rate yields a larger $R^{2}$ value, which implies a more variable currency risk premium. For example, the $R^{2}$ value in the one-month OLS regression

\footnotetext{
3 UIP is actually a statement of the expected level (not log) of excess return, which means that we abstract from a Jensen's inequality term. Here, the important deviation from UIP is a time-varying currency risk premium, not a nonzero but constant currency risk premium.
} 


\section{Table 6}

Properties of the currency risk premium.

This table presents empirical moments (with standard errors in parentheses) for the currency risk premium and the expected depreciation rate, related to the so-called Fama conditions. Moments in the column labeled "Fama regression" derive from OLS estimates of regression (5); moments in the column labeled "Present-value model" derive from the estimation of the present-value model with a constant expected longrun exchange rate (stationary model), as reported in Table 4. Standard errors are computed using the delta method.

\begin{tabular}{lcc}
\hline & $\begin{array}{c}\text { Fama } \\
\text { regression }\end{array}$ & $\begin{array}{c}\text { Present-value } \\
\text { model }\end{array}$ \\
\hline \multicolumn{3}{c}{$\operatorname{Var}\left(\mathrm{E}_{t}\left(r x_{t+1}\right)\right)-\operatorname{Var}\left(\mathrm{E}_{t}\left(\Delta s_{t+1}\right)\right)>0$} \\
$\operatorname{Var}\left(\mathrm{E}_{t}\left(r x_{t+1}\right)\right)-\operatorname{Var}\left(\mathrm{E}_{t}\left(\Delta s_{t+1}\right)\right)$ & 0.092 & 0.099 \\
$($ s.e. $)$ & $(0.037)$ & $(0.030)$ \\
$\operatorname{Var}\left(\mathrm{E}_{t}\left(r x_{t+1}\right)\right)>\operatorname{Cov}\left(\mathrm{E}_{t}\left(r x_{t+1}\right), \mathrm{E}_{t}\left(\Delta s_{t+1}\right)\right)>\operatorname{Var}\left(\mathrm{E}_{t}\left(\Delta s_{t+1}\right)\right)$ \\
$\operatorname{Var}\left(\mathrm{E}_{t}\left(r x_{t+1}\right)\right)$ & 0.118 & 0.206 \\
$(\mathrm{~s} . e)$. & $(0.070)$ & $(0.069)$ \\
$\operatorname{Cov}\left(\mathrm{E}_{t}\left(r x_{t+1}\right), \mathrm{E}_{t}\left(\Delta s_{t+1}\right)\right)$ & 0.056 & 0.141 \\
$(\mathrm{~s} . e)$. & $(0.051)$ & $(0.055)$ \\
$\operatorname{Var}\left(\mathrm{E}_{t}\left(\Delta s_{t+1}\right)\right)$ & 0.027 & 0.107 \\
$($ s.e. $)$ & $(0.033)$ & $(0.044)$ \\
\hline
\end{tabular}

for the currency portfolio increases from $2.2 \%$ to $2.8 \%$, a $31 \%$ increase. Hence, accounting for the real exchange rate implies a more volatile risk premium. However, doing so also affects the variance of the expected depreciation rate. In our model, the difference between the two variances is given by

$$
\begin{aligned}
\operatorname{Var}\left(\mathrm{E}_{t}\left(r x_{t+1}\right)\right)-\operatorname{Var}\left(\mathrm{E}_{t}\left(\Delta s_{t+1}\right)\right)= & (1-2 \beta) \operatorname{Var}\left(i_{t}^{*}-i_{t}\right) \\
& +2 \operatorname{Cov}\left(\eta_{t}, i_{t}^{*}-i_{t}\right)
\end{aligned}
$$

In the absence of a missing risk premium, this difference is positive when $\beta<1 / 2$, as in the data. However, with a missing risk premium, the difference also depends on $\operatorname{Cov}\left(\eta_{t}, i_{t}^{*}-i_{t}\right)$. The net effect is therefore an empirical question.

The covariance condition is that $\operatorname{Var}\left(\mathrm{E}_{t}\left(r x_{t+1}\right)\right)>$ $\operatorname{Cov}\left(\mathrm{E}_{t}\left(r x_{t+1}\right), \mathrm{E}_{t}\left(\Delta s_{t+1}\right)\right)>\operatorname{Var}\left(\mathrm{E}_{t}\left(\Delta s_{t+1}\right)\right)$. In our model, the covariance between the currency risk premium and the expected depreciation rate is:

$$
\begin{aligned}
\operatorname{Cov}\left(\mathrm{E}_{t}\left(r x_{t+1}\right), \mathrm{E}_{t}\left(\Delta s_{t+1}\right)\right)= & \operatorname{Var}\left(\eta_{t}\right)+\beta(\beta-1) \operatorname{Var}\left(i_{t}^{*}-i_{t}\right) \\
& +(1-2 \beta) \operatorname{Cov}\left(\eta_{t}, i_{t}^{*}-i_{t}\right) .
\end{aligned}
$$

In the absence of a missing risk premium, this covariance is positive when $\beta<0$, as $\beta(\beta-1)>0$, consistent with the conditions outlined in Fama (1984) and Bansal and Dahlquist (2000). With a missing risk premium, however, the covariance could be negative if $\operatorname{Cov}\left(\eta_{t}, i_{t}^{*}-i_{t}\right)<0$, as $1-2 \beta>0$. The sign of the covariance is thus also an empirical question.

Table 6 reports the moments related to the variance and covariance conditions. In the first column, we compute the moments using OLS coefficients in the Fama regression and in the second column we compute the moments implied by the estimates of the present-value model parameters. In both cases, the variance difference is positive, meaning that the variance condition continues to hold in the present-value model. Note that our presentvalue estimates imply that the two terms in the differ-

\section{Table 7}

Real exchange rates and interest rate differentials.

This table presents the results of regressing the real exchange rate, $q_{t}$, on the interest rate differential, $i_{t}^{*}-i_{t}$, for the currency portfolio. The first column shows an OLS regression in levels and with Newey and West (1987) standard errors, accounting for conditional heteroskedasticity and serial correlation up to 12 lags, in parenthesis. The second column shows a regression that uses the Cochrane-Orcutt procedure to account for the autocorrelation of the error term and with White (1980) standard errors, accounting for conditional heteroskedasticity. The third column shows an OLS regression in differences with Newey and West (1987) standard errors with three lags.

\begin{tabular}{lccc}
\hline & Level & Cochrane-Orcutt & Difference \\
\hline$b$ & 16.125 & 4.837 & 4.824 \\
$($ s.e. $)$ & $(7.496)$ & $(1.465)$ & $(1.504)$ \\
$R^{2}$ & 0.056 & 0.033 & 0.033 \\
$\mathrm{~N}$ & 532 & 531 & 531 \\
\hline
\end{tabular}

ence have conflicting signs. The first term has a positive sign, as the estimated $\beta$ coefficient is negative. The second term has a negative sign as it is proportional to the covariance between the missing risk premium and the interest rate differential. In Table 6 , the variance difference is greater in the present-value model because the $\beta$ estimate is more negative. This confirms that accounting for the missing risk premium deepens the forward premium puzzle. Table 6 also reports the covariance between the currency risk premium and the expected depreciation rate. Our model estimates satisfy the covariance condition as well.

\subsection{Why does the real exchange rate appreciate with the interest rate differential?}

Absent a missing risk premium in our present-value model, the movements in the real exchange rate are entirely due to movements in the interest rate differential. When UIP holds and $\beta=1$, the real exchange rate equals the present value of expected future interest rate differentials and moves only because of cash flows. The foreign currency is expensive when the interest rate in the foreign country is higher than in the domestic country. When $\beta \neq 1$, the interest rate differential predicts future returns and the real exchange rate also moves because of risk premiums (or discount rates). When $\beta<0$, the discount rate effect dominates so that the foreign currency appears weak when its relative interest rate is high. That is, the $\beta$ coefficient captures the sensitivity of the real exchange rate with respect to both cash flows and discount rate shocks and the persistence in the interest rate differential is central. Hence, in the absence of a missing risk premium, our present-value model predicts that the real exchange rate is perfectly correlated with the expected future interest rate differentials. In addition, this correlation must have the same sign as the $\beta$ coefficient.

Empirically, the correlation between the real exchange rate and the interest rate differential is weak and has the wrong sign. Table 7 reports contemporaneous regressions of the real exchange rate on the interest rate differential 
for the currency portfolio. The first column reports the regression results in levels. The error term in this regression is correlated with $\eta_{t}$ and is likely serially correlated. In the second column, we therefore use a Cochrane-Orcutt estimation method, specifying an AR(1) process for the error term. The third column reports a regression of the change in the real exchange rate on the change in the interest rate differential. Considering changes rather than levels alleviates the potential influence of nonstationary real exchange rates on the estimation of the slope coefficients. Absent a missing risk premium, the $R^{2}$ values should be high and the slope coefficients should be negative. However, the estimated slope coefficients are positive in all cases. While the slope coefficients are imprecisely estimated and there are statistical concerns about the level regression, the $R^{2}$ values are unambiguously low.

One salient result in Table 4 is that the missing risk premium and the interest rate differential shock are negatively correlated. An increase in the domestic interest rate (or a decrease in the foreign interest rate) corresponds to a decrease in the missing risk premium. This is useful for understanding why the real exchange rate appreciates contemporaneously with the interest rate differential. In the model, inflation differentials are unpredictable and the covariance between the real exchange rate and the interest rate differential is:

$$
\begin{aligned}
\operatorname{Cov}\left(q_{t}, i_{t}^{*}-i_{t}\right)= & \operatorname{Cov}\left(\mathrm{E}_{t} \sum_{j=1}^{\infty}\left(i_{t+j-1}^{*}-i_{t+j-1}\right)\right. \\
& \left.-\mathrm{E}_{t} \sum_{j=1}^{\infty} r x_{t+j}, i_{t}^{*}-i_{t}\right), \\
= & \frac{\beta \operatorname{Var}\left(i_{t}^{*}-i_{t}\right)}{1-\rho_{i}}-\frac{\operatorname{Cov}\left(\eta_{t}, i_{t}^{*}-i_{t}\right)}{1-\rho_{\eta}} .
\end{aligned}
$$

The sign of the covariance depends on the $\beta$ coefficient and on the covariance between the missing risk premium and the interest rate differential. As estimates of $\beta$ are often negative, there must be a compensating force to obtain a positive covariance between the real exchange rate and the interest rate differential. This compensating force manifests itself in the negative correlation between the missing risk premium and the interest rate differential. Economically, the short-run effect of an increase in the domestic interest rate is an increase in future expected returns (i.e., $\beta<0$ ), but less than if the missing risk premium is left constant. As the interest rate differential reverts to its mean faster than does the missing risk premium (i.e., $\rho_{i}<\rho_{\eta}$ ), the long-term effect is a decrease in future expected currency returns, as increases in the interest rate differential are associated with a real exchange rate appreciation. The missing risk premium can also capture Engel's (2016) finding that deviations from the UIP reverse over long horizons, which we discuss next.

4.6. Why does the relation between currency risk premiums and the interest rate differential reverse over longer horizons?

Engel (2016) finds that the positive relation between currency risk premiums and the interest rate differential
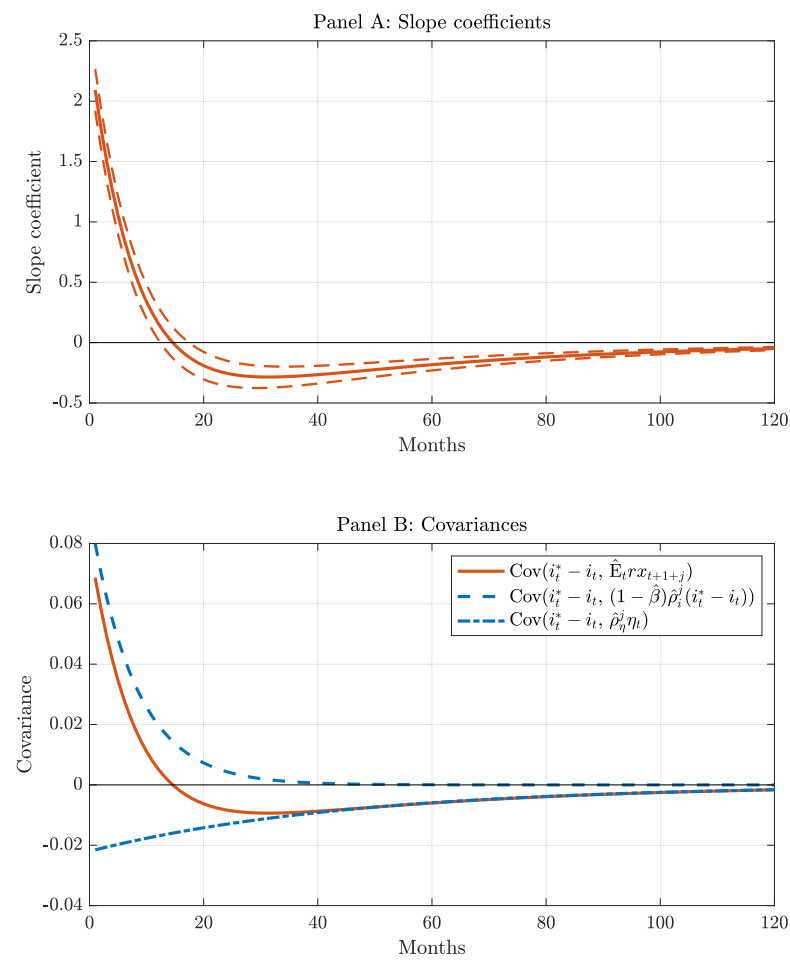

Fig. 3. Long-horizon predictability and the nominal interest rate differential. Panel A shows the slope coefficients and 90\% confidence interval of the regression $\hat{\mathrm{E}}_{t}\left(r x_{t+1+j}\right)=a+b\left(i_{t}^{*}-i_{t}\right)+u_{t+1+j}$ for the currency portfolio and the nominal interest rate differential. Panel $B$ decomposes the covariance of the slope coefficient into the interest rate differential and missing risk premium components.

reverses over longer horizons. Over shorter horizons, a relatively high foreign interest rate is associated with a relatively large currency premium, that is, $\operatorname{Cov}\left(\mathrm{E}_{t}\left(r x_{t+j}\right), i_{t}^{*}-\right.$ $\left.i_{t}\right)>0$. This covariance reflects the usual UIP deviation. This implies that currencies with high interest rates appear riskier to investors. This relation reverses over longer horizons, at which currencies with high interest rates appear relatively safer. Formally, currency risk premiums are negatively correlated with the interest rate differential over an infinite horizon:

$\operatorname{Cov}\left(\mathrm{E}_{t} \sum_{j=1}^{\infty} r x_{t+j}, i_{t}^{*}-i_{t}\right)<0$.

Does our present-value model reproduce this reversal? The model's implied expected return is given by:

$\hat{\mathrm{E}}_{t}\left(r x_{t+1+j}\right)=(1-\hat{\beta}) \hat{\rho}_{i}^{j}\left(i_{t}^{*}-i_{t}\right)+\hat{\rho}_{\eta}^{j} \hat{\eta}_{t}$,

where we use a "hat" on the expectation to emphasize that it is based on estimates from our model, rather than on observable variables. Panel A of Fig. 3 shows, over increasing horizons, the slope coefficients and 90\% confidence interval of the following regression:

$\hat{\mathrm{E}}_{t}\left(r x_{t+1+j}\right)=a+b\left(i_{t}^{*}-i_{t}\right)+u_{t+1+j}$.

The figure plots a positive slope coefficient of around 2.2 over a monthly horizon. In line with our previous results, 
this indicates that currency risk premiums are positively correlated with the interest rate differential. However, the slope coefficient weakens with the horizon and becomes negative after 15 months. This result is strikingly similar to that of Engel (2016), although the model we use to generate expected returns differs from the one he considers.

Panel B of Fig. 3 shows why our model can replicate the changing relation between currency risk premiums and the interest rate differential. The figure plots the covariance between currency risk premiums and the interest rate differential, which mirrors the slope coefficient in Panel A. The figure also plots two components of this covariance. The first component equals $(1-\hat{\beta}) \hat{\rho}_{i}^{j} \operatorname{Var}\left(i_{t}^{*}-i_{t}\right)$ and captures the covariance attributable to the interest rate differential. This component is always positive (as $\hat{\rho}_{i}>0$ ) and decays towards zero as the horizon increases. The second component is $\hat{\rho}_{\eta}^{j} \operatorname{Cov}\left(i_{t}^{*}-i_{t}, \hat{\eta}_{t}\right)$ and captures the covariance between the interest rate differential and the missing risk premium. This component is negative and it also decays towards zero as the horizon increases. As the missing risk premium component of expected returns is much more persistent than the interest rate differential component, the negative missing risk premium effect eventually dominates the positive interest rate differential effect on currency risk premiums.

Our empirical results therefore suggest that not only should asset pricing models feature two risk premiums, but also that these two risk premiums should be negatively correlated and that the missing risk premium should be more persistent than the interest rate differential. These conditions are necessary to reproduce Engel's (2016) finding in our present-value model. Interestingly, these conditions are related, but are quantitatively distinct from the conditions required to obtain a positive covariance between the real exchange rate and interest rate differentials. From Eq. (24), we have that:

$$
\begin{aligned}
\operatorname{Cov}\left(q_{t}, i_{t}^{*}-i_{t}\right)= & \operatorname{Cov}\left(\mathrm{E}_{t} \sum_{j=1}^{\infty}\left(i_{t+j-1}^{*}-i_{t+j-1}\right), i_{t}^{*}-i_{t}\right) \\
& -\operatorname{Cov}\left(\mathrm{E}_{t} \sum_{j=1}^{\infty} r x_{t+j}, i_{t}^{*}-i_{t}\right),
\end{aligned}
$$

which is positive if

$$
\operatorname{Cov}\left(\mathrm{E}_{t} \sum_{j=1}^{\infty} r x_{t+j}, i_{t}^{*}-i_{t}\right)<\operatorname{Cov}\left(\mathrm{E}_{t} \sum_{j=1}^{\infty}\left(i_{t+j-1}^{*}-i_{t+j-1}\right), i_{t}^{*}-i_{t}\right)
$$

Recognize Engel's result (25) on the left-hand side of Eq. (29). As this term is negative, a sufficient condition for the condition to hold is that its right-hand side should be nonnegative. This term depends on the long-term autocorrelations of interest rate differentials and our $\operatorname{AR}(1)$ assumption implies that it is positive.

\section{Alternative present-value models}

In this section, we consider the robustness of our results to additional predictors of currency returns, alterna- tive real interest rate differential dynamics, and a timevarying expected long-run exchange rate.

\subsection{Additional predictors}

Many variables beyond the interest rate differential have been proposed to predict exchange rate movements (Rossi, 2013). In this subsection, we report on two robustness checks. First, we consider the sensitivity of our currency risk premium specification to the inclusion of additional predictors. Second, we evaluate whether models with other predictors, but no missing risk premium, can reproduce Engel's (2016) predictability reversal result that we discuss in Section 4.6.

The real exchange rate is now given by (see Appendix A):

$q_{t}-\mu_{q}=\beta \frac{i_{t}^{*}-i_{t}-\mu_{i}}{1-\rho_{i}}-\gamma \frac{y_{t}}{1-\rho_{y}}-\frac{\eta_{t}}{1-\rho_{\eta}}$.

Appendix A also contains expressions for the currency return, its shock, and the predictability regression.

We consider the following predictive variables: external imbalances (Gourinchas and Rey, 2007; Della Corte et al., 2012; Della Corte et al., 2016) and currency and equity variance risk premiums (Londono and Zhou, 2017). Gourinchas and Rey (2007) propose that NXA, the deviation from trend of a weighted combination of gross assets, gross liabilities, gross exports, and gross imports, has predictive power for future currency returns. The channel follows from a country's intertemporal budget constraint that allows for valuation changes in foreign assets and liabilities. When a country experiences a current account imbalance, the intertemporal budget constraint implies that the country will need to run trade surpluses in the future or earn high returns on the net foreign asset portfolio. Gourinchas and Rey (2007) show that currency return predictability arises when there is a currency mismatch between foreign assets and liabilities. For example, if foreign assets are mostly denominated in foreign currency and foreign liabilities are mostly denominated in domestic currency, the NXA variable will also predict future currency returns with a negative sign (i.e., we expect $\gamma<0$ for NXA).

Londono and Zhou (2017) show that the global currency variance risk premium (XVP) and the stock variance risk premium (VRP) predict currency returns. They argue that a higher XVP indicates greater global uncertainty, and therefore a higher USD safety value for currency investors (i.e., we expect $\gamma<0$ for XVP). They also argue that a higher VRP indicates greater U.S. uncertainty, and therefore higher compensation for currency investors (i.e., we expect $\gamma>0$ for VRP).

We construct the NXA series up to 2015 following Gourinchas and Rey (2007) and Della Corte et al. (2012). We obtained the original XVP data from Juan Londono's website and VP data, extended to 2019, from Hao Zhou's website. The Online Appendix contains additional details.

Table 8 reports the estimated model parameters. The main model parameters are similar to those without additional predictors. The $\gamma$ estimates have the expected 


\section{Table 8}

Estimation of models with additional predictors. This table presents estimates of the present-value models with a constant expected long-run exchange rate but with an additional predictor. Expressions for the models are given in Appendix B. Each column presents estimates for each of the three predictors considered: NXA (the deviation from trend of a weighted combination of gross assets, gross liabilities, gross exports, and gross imports), XVP (the global currency variance risk premium), and VRP (the equity variance risk premium). The models are estimated by maximum likelihood for the currency portfolio. Standard errors are reported in parentheses.

\begin{tabular}{|c|c|c|c|}
\hline & NXA & XVP & VRP \\
\hline $\begin{array}{c}\beta \\
\text { (s.e.) }\end{array}$ & $\begin{array}{r}-1.676 \\
(0.682)\end{array}$ & $\begin{array}{c}-2.024 \\
(0.760)\end{array}$ & $\begin{array}{r}-1.634 \\
(0.650)\end{array}$ \\
\hline $\begin{array}{c}\rho_{i} \\
\text { (s.e.) }\end{array}$ & $\begin{array}{c}0.883 \\
(0.014)\end{array}$ & $\begin{array}{c}0.883 \\
(0.014)\end{array}$ & $\begin{array}{c}0.881 \\
(0.014)\end{array}$ \\
\hline $\begin{array}{c}\sigma_{i} \\
\text { (s.e.) }\end{array}$ & $\begin{array}{c}0.085 \\
(0.001)\end{array}$ & $\begin{array}{c}0.085 \\
(0.001)\end{array}$ & $\begin{array}{c}0.085 \\
(0.001)\end{array}$ \\
\hline $\begin{array}{c}\rho_{\eta} \\
\text { (s.e.) }\end{array}$ & $\begin{array}{c}0.979 \\
(0.008)\end{array}$ & $\begin{array}{c}0.976 \\
(0.009)\end{array}$ & $\begin{array}{c}0.978 \\
(0.008)\end{array}$ \\
\hline $\begin{array}{c}\sigma_{\eta} \\
\text { (s.e.) }\end{array}$ & $\begin{array}{c}0.070 \\
(0.034)\end{array}$ & $\begin{array}{c}0.075 \\
(0.033)\end{array}$ & $\begin{array}{c}0.061 \\
(0.025)\end{array}$ \\
\hline $\begin{array}{c}\rho_{\eta i} \\
\text { (s.e.) }\end{array}$ & $\begin{array}{r}-0.508 \\
(0.162)\end{array}$ & $\begin{array}{r}-0.582 \\
(0.126)\end{array}$ & $\begin{array}{r}-0.591 \\
(0.121)\end{array}$ \\
\hline $\begin{array}{c}\sigma_{y} \\
\text { (s.e.) }\end{array}$ & $\begin{array}{c}3.216 \\
(0.113)\end{array}$ & $\begin{array}{c}0.303 \\
(0.009)\end{array}$ & $\begin{array}{c}0.145 \\
(0.002)\end{array}$ \\
\hline $\begin{array}{c}\rho_{y i} \\
\text { (s.e.) }\end{array}$ & $\begin{array}{c}0.018 \\
(0.110)\end{array}$ & $\begin{array}{c}0.121 \\
(0.088)\end{array}$ & $\begin{array}{c}0.060 \\
(0.056)\end{array}$ \\
\hline $\begin{array}{c}\rho_{y \eta} \\
\text { (s.e.) }\end{array}$ & $\begin{array}{c}0.523 \\
(0.437)\end{array}$ & $\begin{array}{c}0.322 \\
(0.297)\end{array}$ & $\begin{array}{c}-0.157 \\
(0.158)\end{array}$ \\
\hline $\begin{array}{c}\gamma \\
\text { (s.e.) }\end{array}$ & $\begin{array}{r}-0.044 \\
(0.019)\end{array}$ & $\begin{array}{c}-0.706 \\
(0.327)\end{array}$ & $\begin{array}{c}1.761 \\
(0.752)\end{array}$ \\
\hline $\begin{array}{c}\rho_{y} \\
\text { (s.e.) }\end{array}$ & $\begin{array}{c}0.934 \\
(0.018)\end{array}$ & $\begin{array}{c}0.791 \\
(0.021)\end{array}$ & $\begin{array}{c}0.377 \\
(0.030)\end{array}$ \\
\hline Log-likelihood & -1115.7 & -661.8 & -444.2 \\
\hline
\end{tabular}

sign. The Online Appendix reports the corresponding predictability results.

Table 5 reports the associated variance decomposition for the unexpected currency return. The additional predictors explain only a small fraction of the unexpected currency return, the most significant variable being NXA. One reason why other variables remain different from the missing risk premium is that they are less persistent than the real exchange rate. Even the most persistent predictor, NXA, exhibits a half-life of 10.1 months, which is about one third of the real exchange rate's half-life of 31.7 months. To make an analogy with stocks, many variables beyond valuation ratios seem to predict returns, but a valuation ratio such as the price-dividend ratio is the natural variable to consider to understand expected returns and asset prices. Other variables are typically less persistent than valuation ratios, and therefore predict returns over shorter horizons (Cochrane, 2011). ${ }^{4}$

Another way to evaluate whether the missing risk premium is critical is to study Engel's (2016) predictability re-

\footnotetext{
${ }^{4}$ We have also considered past currency returns (Burnside et al., 2011; Menkhoff et al., 2012; Moskowitz et al., 2012), realized currency volatility (Chernov et al., 2018), and funding liquidity aggregates of U.S. financial intermediaries (Adrian et al., 2011). We did not find strong evidence of currency predictability in our sample, which is further confirmed when taking the present-value model to the data (untabulated results).
}

versal in a model lacking a missing risk premium. The Online Appendix reports the slope coefficients of a regression of the expected multiperiod currency return, $\hat{\mathrm{E}}_{t}\left(r x_{t+1+j}\right)$, on the interest rate differential. The specifications that include the real exchange rate reproduce the nonmonotonic relation between the currency risk premium and the interest rate differential, whereas the one that excludes the real exchange rate does not. The reason why other predictor specifications exhibit this monotonic specification is that the premiums corresponding to the additional predictors covary positively with the interest rate differential, whereas the missing risk premium exhibits a negative correlation.

\subsection{Alternative real interest rate dynamics}

In this subsection, we consider alternative approaches to modeling the real interest rate differential. The real exchange rate is a function of expected real interest rate differentials and, with our assumption of nonpersistent inflation differentials, the expected real interest rate differential is perfectly correlated with the nominal interest rate differential. We argued earlier that this is a good approximation of the data. However, other papers in the literature have proposed different assumptions. One example is that of Campbell and Clarida (1987), who treat the expected real interest rate differential as a latent state variable with $\mathrm{AR}(1)$ dynamics. Unfortunately, one cannot then simultaneously identify a missing risk premium. Another example is that of Balduzzi and Chiang (2020), who replace the expected realized real interest rate differentials with the real interest rate differentials. This effectively lowers the persistence of the expected real interest rate differentials, amplifying the disconnect between the interest rate differentials and the real exchange rate.

We consider two robustness checks. First, we relax our assumption that the autocorrelation of the inflation differentials is zero and instead assume that it follows an $\mathrm{AR}(1)$ process. This approach is more general than the assumption of Balduzzi and Chiang (2020), which amounts to assuming that the interest rate and inflation differentials have the same persistence. If the expected inflation differential is persistent, then the real exchange rate also depends on the current inflation differential. This implies that the current inflation differential should predict currency returns. We find that this is not the case (see the Online Appendix).

Second, we treat the expected real interest rate differential as an $\operatorname{AR}(1)$ latent variable, but estimate this variable outside our state-space model. In the spirit of Schorfheide et al. (2018), we estimate it as the fitted value of a projection of the realized real interest rate differential on the current nominal interest rate differential and the inflation differential over the previous month. This real interest rate differential also predicts the currency premium (see the Online Appendix), which suggests that we can replace the nominal interest rate differential with the expected real interest rate differential. We find similar model estimates (see the Online Appendix), and the variance decomposition in Table 5 suggests that the missing risk pre- 
mium is again capturing most of the variation in unexpected returns.

\subsection{Time-varying expected long-run exchange rate}

In this subsection, we consider a present-value model with a time-varying expected long-run exchange rate. As in Campbell and Clarida (1987), we assume that the expected long-run exchange rate follows a random walk:

$\omega_{t+1}=\omega_{t}+\varepsilon_{t+1}^{\omega}$,

where $\varepsilon_{t+1}^{\omega}$ is IID over time (but potentially crosscorrelated with other shocks). The expression for the real exchange rate now becomes (see Appendix A):

$q_{t}-\omega_{t}=\beta \frac{i_{t}^{*}-i_{t}-\mu_{i}}{1-\rho_{i}}-\frac{\eta_{t}}{1-\rho_{\eta}}$.

This expression is similar to (12), but the real exchange rate is adjusted for the time-varying expected long-run exchange rate. This is natural because, under the random walk assumption (31), the real exchange rate, $q_{t}$, is nonstationary while the adjusted exchange rate, $q_{t}-\omega_{t}$, is stationary. Now, the expected long-run exchange rate can potentially rationalize the disconnect between interest rates and the real exchange rate that we discussed in Section 4.5.

Relaxing the stationarity assumption for the real exchange rate requires a model that accommodates another unobserved variable corresponding to the expected longrun exchange rate, $\omega_{t}$, so that the state vector becomes $X_{t}=\left[i_{t}^{*}-i_{t}, \eta_{t}, \omega_{t}\right]$. The dynamics of the expected long-run exchange rate are given by Eq. (31). We assume the following covariance matrix:

$\operatorname{Var}\left(\left[\begin{array}{c}\varepsilon_{t}^{i} \\ \varepsilon_{t}^{\eta} \\ \varepsilon_{t}^{\omega}\end{array}\right]\right)=\left[\begin{array}{ccc}\sigma_{i}^{2} & \sigma_{\eta i} & \sigma_{\omega i} \\ \sigma_{\eta i} & \sigma_{\eta}^{2} & 0 \\ \sigma_{\omega i} & 0 & \sigma_{\omega}^{2}\end{array}\right]$,

where the expected long-run exchange rate shock is uncorrelated with the missing risk premium shock (i.e., $\sigma_{\eta \omega}=$ 0 ), as Rytchkov (2012) shows in a similar setting that at least one element of the covariance matrix must be fixed for the model to be identified. The model thus contains only two extra parameters, $\sigma_{\omega}$ and $\rho_{\omega i}$. The full state-space model is given in Appendix $B$.

The above model imposes little structure on the expected long-run exchange rate, except that it is uncorrelated with the missing risk premium and follows a random walk. We can take cues from economic theory to consider an extended model that imposes further structure on the expected long-run exchange rate. Irrespective of whether or not the real exchange rate is stationary, we want to confirm that we are not misattributing real exchange rate variations to the missing risk premium. We consider two mechanisms that create sticky deviations from PPP, making the real exchange rate appear nonstationary in the data.

First, the Harrod-Balassa-Samuelson (HBS) effect states that more productive countries have stronger real exchange rates. The key idea is that productivity tends to differ more in the traded sectors (e.g., manufacturing) than in the nontraded sectors (e.g., locally rendered services). If wages in the nontraded sectors follow wages in the traded sectors, more productive countries will have strong real exchange rates. Therefore, productivity differentials impart persistence to the real exchange rate.

Second, the literature suggests a link between deviations from PPP and the net international asset position. The transfer problem predicts that debtor countries require weaker real exchange rates [see Taylor and Taylor (2004) for a survey]. For instance, in a small open economy, an increase in external debt means that the country will run a trade surplus in the future to service the interest payments due. The real exchange rate could then depreciate so that the country's net exports increase to compensate for the decline in its net foreign assets. Lane and Milesi-Ferretti (2004) provide supporting evidence. Campbell and Clarida (1987) suggest a different mechanism to explain the simultaneous real appreciation of the dollar in 1980-1985, which coincided with an increase in real interest rates. They argue that an increase in spending on domestic goods, which raises the current account deficit (a fall in net foreign assets), induces the real exchange rate to appreciate and the interest rate differential to decrease. They remark that this can rationalize the positive correlation between shocks to the expected longrun exchange rate and shocks to the interest rate differential observed in the data.

These two mechanisms suggest that the real exchange rate moves for reasons beyond changes in risk premiums; they also imply that these movements are related to observable macroeconomic variables. Motivated by the HBS effect, Chong et al. (2012) use the difference in GDP per capita to proxy for productivity differentials. They posit a cointegration relation between the real exchange rate and the GDP differentials, $x_{t}$, so that $q_{t}-\lambda x_{t}$ is stationary (where $\lambda$ is a constant parameter). Cast within a presentvalue model, this relation amounts to assuming that the expected long-run exchange rate, $\omega_{t}$, is observed and equal to $\lambda x_{t}$. Following Menkhoff et al. (2017), we consider other variables that can contain information about $\omega_{t}$. Conveniently, our filtering approach allows us to weaken the relation between $\omega_{t}$ and $x_{t}$ by allowing for a measurement error:

$x_{t}=\omega_{t} / \lambda+v_{t}^{x}$,

where $v_{t}^{x}$ is an IID shock with a volatility of $\sigma_{x}$. We now have an additional measurement equation. The model remains parsimonious as it includes only two extra parameters: $\sigma_{x}$ and $\lambda$.

We consider the following variables for $x_{t}$ : productivity (the difference between the foreign and U.S. real GDP per capita), quality (the difference between the foreign and U.S. quality of export goods), and U.S. net foreign assets. Productivity and quality capture the HBS effect, whereas net foreign assets captures the international asset position mechanisms. The HBS effect predicts that more productive countries have appreciated real exchange rates $(\lambda>0)$. The transfer problem predicts a negative relation between U.S. net foreign assets and the real exchange rate $(\lambda<0)$, whereas the mechanism proposed by Campbell and Clarida (1987) predicts a positive relation $(\lambda>0)$.

Table 9 reports summary statistics for the productivity, quality, and net foreign assets of the portfolio. Produc- 


\section{Table 9}

Macroeconomic variables: Summary statistics.

This table presents means, standard deviations, and first-order autocorrelations for macroeconomic variables, averaged at the portfolio level. Productivity refers to the real GDP per capita averaged across the seven countries in the portfolio minus the U.S. real GDP per capita. Quality refers to the difference between the foreign and U.S. measurements of the quality of export goods, as constructed by Henn et al. (2020). Net foreign assets refers to the difference between U.S. external assets and liabilities, as constructed by Lane and Milesi-Ferretti (2007), scaled by GDP. Productivity is sampled quarterly, whereas quality and net foreign assets are sampled yearly. Standard deviations and autocorrelation coefficients are expressed on a monthly basis to be comparable to the variables in Table 1.

\begin{tabular}{lccc}
\hline & Productivity & Quality & Net foreign assets \\
\hline Sample begins & $76 . Q 2$ & 1976 & 1976 \\
Sample ends: & $20 . \mathrm{Q} 1$ & 2014 & 2015 \\
Mean (\%) & -11.659 & -2.567 & -10.812 \\
S.D. (\%) & 1.018 & 0.327 & 3.826 \\
AC(1) & 0.981 & 0.985 & 0.987 \\
\hline
\end{tabular}

tivity is measured simply as the difference between the foreign and U.S. real GDP per capita; we obtain quarterly GDP and yearly population data from the OECD to create quarterly real GDP per capita. Quality is measured as the difference between the foreign and U.S. quality of export goods; we obtain annual observations up to 2014 from the International Monetary Fund [see Henn et al. (2020) for a detailed description of the data]. We obtain annual observations of U.S. net foreign assets divided by GDP up to 2015 from Lane and Milesi-Ferretti (2007). The United States has on average been more productive and has exported products of higher quality than have the countries in the portfolio. The U.S. net foreign assets divided by GDP have been declining over the period and average around $-10.8 \%$. Most importantly for capturing variation in the expected long-run exchange rate, these variables display a high degree of persistence, having first-order autocorrelations close to one. The variables are sampled at lower frequencies, and quality and net foreign assets are available only until 2014 and 2015, respectively, but this can be handled in the model estimation since the Kalman filter can evaluate the model's likelihood even with missing observations.

Table 10 presents the parameter estimates for the models with a time-varying expected long-run exchange rate. The main coefficients of interest are similar to those of the baseline model. The coefficients related to the missing risk premium, in particular, are essentially the same. In models with additional measurement variables, the $\lambda$ estimates are positive, as predicted by the HBS effect and the mechanism proposed by Campbell and Clarida (1987), but imprecisely estimated. In the model without additional variables, we also observe that the expected long-run exchange rate shock and the interest differential shock are positively correlated. However, the positive correlation between the interest rate differential and the expected longrun exchange rate essentially disappears once we allow for measurements of the expected long-run exchange rate.

The log-likelihood value for the nonstationary model without an additional measurement variable is close to the log-likelihood value for the baseline model. Formally, a likelihood ratio test cannot reject the restricted station-
Table 10

Estimation of models with a time-varying expected long-run exchange rate.

This table presents estimates of the present-value models with a timevarying expected long-run exchange rate (nonstationary models). Expressions for the models are given in Appendix B. The model in the first column is the model with a time-varying expected long-run exchange rate; the remaining models are the extended models with an additional measurement variable: Productivity, Quality, or Net foreign assets. The models are estimated by maximum likelihood for the currency portfolio. Standard errors are reported in parentheses.

\begin{tabular}{|c|c|c|c|c|}
\hline$x$ variable: & - & Productivity & Quality & $\begin{array}{l}\text { Net foreign } \\
\text { assets }\end{array}$ \\
\hline $\begin{array}{c}\beta \\
\text { (s.e.) }\end{array}$ & $\begin{array}{r}-2.330 \\
(0.671)\end{array}$ & $\begin{array}{r}-1.739 \\
(0.660)\end{array}$ & $\begin{array}{r}-1.641 \\
(0.645)\end{array}$ & $\begin{array}{c}-1.724 \\
(0.667)\end{array}$ \\
\hline $\begin{array}{c}\rho_{i} \\
\text { (s.e.) }\end{array}$ & $\begin{array}{c}0.893 \\
(0.013)\end{array}$ & $\begin{array}{c}0.883 \\
(0.014)\end{array}$ & $\begin{array}{c}0.882 \\
(0.014)\end{array}$ & $\begin{array}{c}0.881 \\
(0.014)\end{array}$ \\
\hline $\begin{array}{c}\sigma_{i} \\
\text { (s.e.) }\end{array}$ & $\begin{array}{c}0.085 \\
(0.001)\end{array}$ & $\begin{array}{c}0.085 \\
(0.001)\end{array}$ & $\begin{array}{c}0.085 \\
(0.001)\end{array}$ & $\begin{array}{c}0.085 \\
(0.001)\end{array}$ \\
\hline $\begin{array}{c}\rho_{\eta} \\
\text { (s.e.) }\end{array}$ & $\begin{array}{c}0.970 \\
(0.006)\end{array}$ & $\begin{array}{c}0.979 \\
(0.008)\end{array}$ & $\begin{array}{c}0.979 \\
(0.008)\end{array}$ & $\begin{array}{c}0.977 \\
(0.008)\end{array}$ \\
\hline $\begin{array}{c}\sigma_{\eta} \\
\text { (s.e.) }\end{array}$ & $\begin{array}{c}0.096 \\
(0.022)\end{array}$ & $\begin{array}{c}0.061 \\
(0.025)\end{array}$ & $\begin{array}{c}0.057 \\
(0.025)\end{array}$ & $\begin{array}{c}0.064 \\
(0.026)\end{array}$ \\
\hline $\begin{array}{c}\rho_{\eta i} \\
\text { (s.e.) }\end{array}$ & $\begin{array}{c}-0.553 \\
(0.201)\end{array}$ & $\begin{array}{c}-0.610 \\
(0.120)\end{array}$ & $\begin{array}{c}-0.614 \\
(0.123)\end{array}$ & $\begin{array}{c}-0.611 \\
(0.122)\end{array}$ \\
\hline $\begin{array}{c}\sigma_{\omega} \\
\text { (s.e.) }\end{array}$ & $\begin{array}{c}0.715 \\
(0.432)\end{array}$ & $\begin{array}{c}0.083 \\
(0.254)\end{array}$ & $\begin{array}{c}0.661 \\
(0.378)\end{array}$ & $\begin{array}{c}0.511 \\
(0.368)\end{array}$ \\
\hline $\begin{array}{c}\rho_{\omega i} \\
\text { (s.e.) }\end{array}$ & $\begin{array}{c}0.833 \\
(0.134)\end{array}$ & $\begin{array}{c}0.055 \\
(0.086)\end{array}$ & $\begin{array}{c}-0.024 \\
(0.184)\end{array}$ & $\begin{array}{c}0.020 \\
(0.126)\end{array}$ \\
\hline $\begin{array}{c}\lambda \\
\text { (s.e.) }\end{array}$ & & $\begin{array}{c}0.034 \\
(0.106)\end{array}$ & $\begin{array}{c}0.455 \\
(0.280)\end{array}$ & $\begin{array}{c}0.394 \\
(0.280)\end{array}$ \\
\hline $\begin{array}{c}\sigma_{x} \\
\text { (s.e.) }\end{array}$ & & $\begin{array}{c}0.984 \\
(0.616)\end{array}$ & $\begin{array}{c}3.588 \\
(1.294)\end{array}$ & $\begin{array}{c}0.784 \\
(2.585)\end{array}$ \\
\hline Log-likelihood & -630.7 & -1141.5 & -760.5 & -747.6 \\
\hline
\end{tabular}

ary model versus the nonstationary model (the $p$-value in a likelihood ratio test is 0.64 ). This is expected given that very long samples are necessary to meaningfully reject PPP. ${ }^{5}$ The economic mechanisms highlighted above suggest that the expected long-run exchange rate does vary over time, although the magnitude of this variation remains to be measured. The variance explained by the expected longrun exchange rate in Table 5 is small and precisely estimated. Overall, our economic message is unchanged: most of the variation in the real exchange rate corresponds to the missing risk premium.

\section{Conclusions}

There is ample evidence that UIP does not hold and that the currency risk premium is time varying; the general tenet in the literature is that the currency risk premium depends on the interest rate differential. We present a present-value model of the real exchange rate in which the risk premium depends on another latent component: a missing risk premium. The model suggests that not only the interest rate differential but also the real exchange rate predicts currency returns. We use the Kalman filter to extract the missing risk premium component. We find that the missing risk premium, not the interest rate differen-

\footnotetext{
5 We note that likelihood ratio tests face a number of practical limitations, including sensitivity to the normality assumption. Also, the null hypotheses we consider are composite, which creates a nuisance parameter problem.
} 
tial, accounts for most of the movements of the real exchange rate and unexpected currency returns. These results hold when we let the expected long-run exchange rate be constant or time varying and include additional predictors, and are robust to alternative real interest rate dynamics.

A missing risk premium can explain three key observations considered in the literature, namely, that the real exchange rate appreciates with the interest rate differential, that the real exchange rate predicts currency returns, and that the positive relation between currency risk premiums and the interest rate differential reverses over longer horizons. Our present-value model sheds light on the desirable properties of currency risk premiums that asset pricing models must accommodate.

\section{Appendix A. Expressions for the present-value models}

This appendix presents the derivation of expressions for the present-value model. We start with a general model with nonstationarity and an omitted predictor and derive the models in the text as special cases.

The real exchange rate

Begin with the currency return (2):

$r x_{t+1}=q_{t+1}-q_{t}-\left(\pi_{t+1}^{*}-\pi_{t+1}\right)+\left(i_{t}^{*}-i_{t}\right)$.

Rewrite it in terms of the real exchange rate:

$q_{t}=\left(i_{t}^{*}-i_{t}\right)-\left(\pi_{t+1}^{*}-\pi_{t+1}\right)-r x_{t+1}+q_{t+1}$.

Iterate forward and take conditional expectations:

$q_{t}=\sum_{j=1}^{T} \mathrm{E}_{t}\left[\left(i_{t+j-1}^{*}-i_{t+j-1}\right)-\left(\pi_{t+j}^{*}-\pi_{t+j}\right)-r x_{t+j}\right]+q_{t+T}$.

Let $T \rightarrow \infty$ and $\lim _{j \rightarrow \infty} \mathrm{E}_{t}\left(q_{t+j}\right)=\omega_{t}$, giving:

$q_{t}-\omega_{t}=\sum_{j=1}^{\infty} \mathrm{E}_{t}\left[\left(i_{t+j-1}^{*}-i_{t+j-1}\right)-\left(\pi_{t+j}^{*}-\pi_{t+j}\right)-r x_{t+j}\right]$,

which corresponds to Eq. (3). According to the currency risk premium in Eq. (6) and the modeling of the real interest rate differential in Eqs. (7) and (8), we obtain:

$$
\begin{aligned}
q_{t}-\omega_{t}= & \sum_{j=1}^{\infty} \mathrm{E}_{t}\left[\left(i_{t+j-1}^{*}-i_{t+j-1}\right)-\left(\pi_{t+j}^{*}-\pi_{t+j}\right)-\alpha\right. \\
& \left.-(1-\beta)\left(i_{t+j-1}^{*}-i_{t+j-1}\right)-\gamma y_{t+j-1}-\eta_{t+j-1}-\varepsilon_{t+j}^{r x}\right] \\
= & \sum_{j=1}^{\infty} \mathrm{E}_{t}\left[\beta\left(i_{t+j-1}^{*}-i_{t+j-1}\right)-\mu_{\pi}-\varepsilon_{t+j}^{\pi}-\alpha\right. \\
& \left.-\gamma y_{t+j-1}-\eta_{t+j-1}-\varepsilon_{t+j}^{r x}\right] \\
= & \sum_{j=1}^{\infty} \mathrm{E}_{t}\left[\beta\left(i_{t+j-1}^{*}-i_{t+j-1}-\mu_{i}\right)+\beta \mu_{i}-\mu_{\pi}\right. \\
& \left.-\alpha-\gamma y_{t+j-1}-\eta_{t+j-1}\right] .
\end{aligned}
$$

Note that $\mathrm{E}\left(q_{t}\right)=\omega_{t}$ implies that $\alpha=\beta \mu_{i}-\mu_{\pi}$. Finally, since $i_{t}^{*}-i_{t}, y_{t}$, and $\eta_{t}$ follow $\operatorname{AR}(1)$ processes, we can use the geometric formula for an expected AR(1) process to obtain:

$$
\begin{aligned}
q_{t}-\omega_{t} & =\sum_{j=1}^{\infty}\left[\beta \rho_{i}^{j-1}\left(i_{t}^{*}-i_{t}-\mu_{i}\right)-\gamma \rho_{y}^{j-1} y_{t}-\rho_{\eta}^{j-1} \eta_{t}\right] \\
& =\beta \frac{i_{t}^{*}-i_{t}-\mu_{i}}{1-\rho_{i}}-\gamma \frac{y_{t}}{1-\rho_{y}}-\frac{\eta_{t}}{1-\rho_{\eta}} .
\end{aligned}
$$

If the expected long-run exchange rate is constant $\left(\omega_{t}=\right.$ $\left.\mu_{\omega}\right)$ and there is no additional predictor $(\gamma=0)$, we obtain Eq. (12). If instead there is an additional predictor $(\gamma \neq 0)$, we obtain Eq. (30). Finally, if the expected long-run exchange rate is time varying, we obtain Eq. (32).

The predictability regression

Take the time difference of Eq. (A.6):

$$
\begin{aligned}
q_{t+1}-q_{t}= & \beta \mu_{i}-\beta\left(i_{t}^{*}-i_{t}\right)+\gamma y_{t}+\eta_{t}+\beta \frac{\varepsilon_{t+1}^{i}}{1-\rho_{i}} \\
& -\gamma \frac{\varepsilon_{t+1}^{y}}{1-\rho_{y}}-\frac{\varepsilon_{t+1}^{\eta}}{1-\rho_{\eta}}+\varepsilon_{t+1}^{\omega} .
\end{aligned}
$$

Add the interest rate differential on both sides to obtain:

$$
\begin{aligned}
r x_{t+1}= & \beta \mu_{i}-\mu_{\pi}+(1-\beta)\left(i_{t}^{*}-i_{t}\right)+\gamma y_{t}+\eta_{t} \\
& +\beta \frac{\varepsilon_{t+1}^{i}}{1-\rho_{i}}-\gamma \frac{\varepsilon_{t+1}^{y}}{1-\rho_{y}}-\frac{\varepsilon_{t+1}^{\eta}}{1-\rho_{\eta}}-\varepsilon_{t+1}^{\pi}+\varepsilon_{t+1}^{\omega} .
\end{aligned}
$$

It follows that the return shock can be expressed in terms of the model's underlying shocks:

$$
\begin{aligned}
\varepsilon_{t+1}^{r x}= & r x_{t+1}-\mathrm{E}_{t}\left(r x_{t+1}\right)=\beta \frac{\varepsilon_{t+1}^{i}}{1-\rho_{i}}-\gamma \frac{\varepsilon_{t+1}^{y}}{1-\rho_{y}}-\frac{\varepsilon_{t+1}^{\eta}}{1-\rho_{\eta}} \\
& -\varepsilon_{t+1}^{\pi}+\varepsilon_{t+1}^{\omega} .
\end{aligned}
$$

Similarly, Eq. (A.6) suggests a new expression for the missing risk premium:

$\eta_{t}=\left(1-\rho_{\eta}\right)\left[\beta \frac{i_{t}^{*}-i_{t}-\mu_{i}}{1-\rho_{i}}-\gamma \frac{y_{t}}{1-\rho_{y}}-\left(q_{t}-\omega_{t}\right)\right]$.

The Fama regression becomes:

$r x_{t+1}=\alpha+(1-\beta)\left(i_{t}^{*}-i_{t}\right)+\eta_{t}+\gamma y_{t}+\varepsilon_{t+1}^{r x}$.

Insert Eq. (A.10) into Eq. (A.11) to obtain:

$$
\begin{aligned}
r x_{t+1}= & \beta \mu_{i}\left(\frac{\rho_{\eta}-\rho_{i}}{1-\rho_{i}}\right)-\mu_{\pi}+\left(1-\beta \frac{\rho_{\eta}-\rho_{i}}{1-\rho_{i}}\right)\left(i_{t}^{*}-i_{t}\right) \\
& +\gamma y_{t}+\left(\rho_{\eta}-1\right)\left(q_{t}-\omega_{t}\right)+\varepsilon_{t+1}^{r x} .
\end{aligned}
$$

If the expected long-run exchange rate is constant $\left(\omega_{t}=\mu_{\omega}\right)$ and there is no additional predictor $(\gamma=0)$, Eqs. (A.9) and (A.12) yield Eqs. (13) and (14).

\section{Appendix B. State-space specifications}

This appendix presents the state-space systems for the models we consider: the baseline model with a constant expected long-run exchange rate, the model with an additional predictor, the model with a time-varying expected long-run exchange rate, and the model with a time-varying expected long-run exchange rate and an additional measurement variable. 


\section{Baseline model}

The state-space system is:

$\left[\begin{array}{c}q_{t} \\ i_{t}^{*}-i_{t}\end{array}\right]=\left[\begin{array}{ll}\frac{\beta}{1-\rho_{i}} & \frac{-1}{1-\rho_{\eta}} \\ 1 & 0\end{array}\right]\left[\begin{array}{c}i_{t}^{*}-i_{t} \\ \eta_{t}\end{array}\right]$,

$\left[\begin{array}{c}i_{t}^{*}-i_{t} \\ \eta_{t}\end{array}\right]=\left[\begin{array}{cc}\rho_{i} & 0 \\ 0 & \rho_{\eta}\end{array}\right]\left[\begin{array}{c}i_{t-1}^{*}-i_{t-1} \\ \eta_{t-1}\end{array}\right]+\left[\begin{array}{c}\varepsilon_{t}^{i} \\ \varepsilon_{t}^{\eta}\end{array}\right]$

with

$\operatorname{Var}\left(\left[\begin{array}{c}\varepsilon_{t}^{i} \\ \varepsilon_{t}^{\eta}\end{array}\right]\right)=\left[\begin{array}{ll}\sigma_{i}^{2} & \sigma_{\eta i} \\ \sigma_{\eta i} & \sigma_{\eta}^{2}\end{array}\right]$

The model parameters are: $\rho_{i}, \sigma_{i}, \beta, \rho_{\eta}, \sigma_{\eta}$, and $\rho_{\eta i}$.

\section{Model with an additional predictor}

The state-space system is:

$\left[\begin{array}{c}q_{t} \\ i_{t}^{*}-i_{t} \\ y_{t}\end{array}\right]=\left[\begin{array}{lll}\frac{\beta}{1-\rho_{i}} & \frac{-1}{1-\rho_{\eta}} & \frac{-\gamma}{1-\rho_{y}} \\ 1 & 0 & 0 \\ 0 & 0 & 1\end{array}\right]\left[\begin{array}{c}i_{t}^{*}-i_{t} \\ \eta_{t} \\ y_{t}\end{array}\right]$,
$\left[\begin{array}{c}i_{t}^{*}-i_{t} \\ \eta_{t} \\ y_{t}\end{array}\right]=\left[\begin{array}{lll}\rho_{i} & 0 & 0 \\ 0 & \rho_{\eta} & 0 \\ 0 & 0 & \rho_{y}\end{array}\right]\left[\begin{array}{c}i_{t-1}^{*}-i_{t-1} \\ \eta_{t-1} \\ y_{t-1}\end{array}\right]+\left[\begin{array}{c}\varepsilon_{t}^{i} \\ \varepsilon_{t}^{\eta} \\ \varepsilon_{t}^{y}\end{array}\right]$,

with

$\operatorname{Var}\left(\left[\begin{array}{c}\varepsilon_{t}^{i} \\ \varepsilon_{t}^{\eta} \\ \varepsilon_{t}^{y}\end{array}\right]\right)=\left[\begin{array}{lll}\sigma_{i}^{2} & \sigma_{\eta i} & \sigma_{y i} \\ \sigma_{\eta i} & \sigma_{\eta}^{2} & \sigma_{y \eta} \\ \sigma_{y i} & \sigma_{y \eta} & \sigma_{y}^{2}\end{array}\right]$

The model parameters are: $\beta, \rho_{i}, \sigma_{i}, \rho_{\eta}, \sigma_{\eta}, \rho_{\eta i}, \sigma_{y}, \rho_{y i}$, $\rho_{y \eta}, \gamma$, and $\rho_{y}$.

\section{Model with a time-varying expected long-run exchange rate}

The state-space system is:

$$
\begin{aligned}
& {\left[\begin{array}{c}
q_{t} \\
i_{t}^{*}-i_{t}
\end{array}\right]=\left[\begin{array}{lll}
\frac{\beta}{1-\rho_{i}} & \frac{-1}{1-\rho_{\eta}} & 1 \\
1 & 0 & 0
\end{array}\right]\left[\begin{array}{c}
i_{t}^{*}-i_{t} \\
\eta_{t} \\
\omega_{t}
\end{array}\right],} \\
& {\left[\begin{array}{c}
i_{t}^{*}-i_{t} \\
\eta_{t} \\
\omega_{t}
\end{array}\right]=\left[\begin{array}{lll}
\rho_{i} & 0 & 0 \\
0 & \rho_{\eta} & 0 \\
0 & 0 & 1
\end{array}\right]\left[\begin{array}{c}
i_{t-1}^{*}-i_{t-1} \\
\eta_{t-1} \\
\omega_{t-1}
\end{array}\right]+\left[\begin{array}{c}
\varepsilon_{t}^{i} \\
\varepsilon_{t}^{\eta} \\
\varepsilon_{t}^{\omega}
\end{array}\right],}
\end{aligned}
$$

with

$$
\operatorname{Var}\left(\left[\begin{array}{c}
\varepsilon_{t}^{i} \\
\varepsilon_{t}^{\eta} \\
\varepsilon_{t}^{\omega}
\end{array}\right]\right)=\left[\begin{array}{lll}
\sigma_{i}^{2} & \sigma_{\eta i} & \sigma_{\omega i} \\
\sigma_{\eta i} & \sigma_{\eta}^{2} & 0 \\
\sigma_{\omega i} & 0 & \sigma_{\omega}^{2}
\end{array}\right]
$$

The model parameters are: $\rho_{i}, \sigma_{i}, \beta, \rho_{\eta}, \sigma_{\eta}, \rho_{\eta i}, \sigma_{\omega}$, and $\rho_{\omega i}$.

\section{Extended model with a time-varying expected long-run exchange rate}

The state-space system is:

$$
\left[\begin{array}{c}
q_{t} \\
i_{t}^{*}-i_{t} \\
x_{t}
\end{array}\right]=\left[\begin{array}{lll}
\frac{\beta}{1-\rho_{i}} & \frac{-1}{1-\rho_{\eta}} & 1 \\
1 & 0 & 0 \\
0 & 0 & \frac{1}{\lambda}
\end{array}\right]\left[\begin{array}{c}
i_{t}^{*}-i_{t} \\
\eta_{t} \\
\omega_{t}
\end{array}\right]+\left[\begin{array}{c}
0 \\
0 \\
v_{t}^{x}
\end{array}\right]
$$

$$
\left[\begin{array}{c}
i_{t}^{*}-i_{t} \\
\eta_{t} \\
\omega_{t}
\end{array}\right]=\left[\begin{array}{lll}
\rho_{i} & 0 & 0 \\
0 & \rho_{\eta} & 0 \\
0 & 0 & 1
\end{array}\right]\left[\begin{array}{c}
i_{t-1}^{*}-i_{t-1} \\
\eta_{t-1} \\
\omega_{t-1}
\end{array}\right]+\left[\begin{array}{c}
\varepsilon_{t}^{i} \\
\varepsilon_{t}^{\eta} \\
\varepsilon_{t}^{\omega}
\end{array}\right],
$$

with

$\operatorname{Var}\left(v_{t}^{x}\right)=\sigma_{x}^{2}$,

and

$\operatorname{Var}\left(\left[\begin{array}{c}\varepsilon_{t}^{i} \\ \varepsilon_{t}^{\eta} \\ \varepsilon_{t}^{\omega}\end{array}\right]\right)=\left[\begin{array}{lll}\sigma_{i}^{2} & \sigma_{\eta i} & \sigma_{\omega i} \\ \sigma_{\eta i} & \sigma_{\eta}^{2} & 0 \\ \sigma_{\omega i} & 0 & \sigma_{\omega}^{2}\end{array}\right]$

The model parameters are: $\rho_{i}, \sigma_{i}, \beta, \rho_{\eta}, \sigma_{\eta}, \rho_{\eta i}, \sigma_{\omega}, \rho_{\omega i}$, $\lambda$, and $\sigma_{x}$.

\section{References}

Adrian, T., Etula, E., Shin, H. S., 2011. Risk appetite and exchange rates. Federal Reserve Bank of New York Staff Report no. 361.

Bacchetta, P., Van Wincoop, E., 2010. Infrequent portfolio decisions: a solution to the forward discount puzzle. Am. Econ. Rev. 100 (3), 870-904.

Backus, D.K., Foresi, S., Telmer, C.I., 2001. Affine term structure models and the forward premium anomaly. J. Finance 56 (1), 279-304. doi:10.1111/0022-1082.00325.

Balduzzi, P., Chiang, I.-H.E., 2020. Real exchange rates and currency risk premia. Rev. Asset Pricing Stud. 10, 94-121.

Bansal, R., Dahlquist, M., 2000. The forward premium puzzle: different tales from developed and emerging economies. J. Int. Econ. 51, 115-144.

Binsbergen, J.H., Koijen, R.S.J., 2010. Predictive regressions: a present-value approach. J. Finance 65 (4), 1439-1471.

Boudoukh, J., Richardson, M., Whitelaw, R.F., 2016. New evidence on the forward premium puzzle. J. Financ. Quant. Anal. 51 (3), 875-897.

Brunnermeier, M.K., Nagel, S., Pedersen, L.H., 2009. Carry trades and currency crashes. In: Acemoglu, D., Rogoff, K., Woodford, M. (Eds.), NBER Macroeconomics Annual, Volume XXIII. MIT Press, Cambridge, pp. 313-347.

Burnside, C., Eichenbaum, M., Rebelo, S., 2011. Carry trade and momentum in currency markets. Annu. Rev. Financ. Econ. 3 (1), 511-535. doi:10. 1146/annurev-financial-102710-144913.

Burstein, A., Gopinath, G., 2014. International prices and exchange rates. In: Gopinath, G., Helpman, E., Rogoff, K. (Eds.), Handbook of International Economics, Volume IV. Elsevier, Amsterdam, pp. 391-451.

Campbell, J.Y., Clarida, R.H., 1987. The dollar and real interest rates. Carnegie-Rochester Conf. Ser. Public Policy 27 (C), 103-139. doi:10. 1016/0167-2231(87)90005-4.

Campbell, J.Y., Shiller, R.J., 1988. The dividend-price ratio and expectations of future dividends and discount factors. Rev. Financ. Stud. 1 (3), 195-228.

Chernov, M., Creal, D., 2021. The PPP view of multihorizon currency risk premiums. Rev. Financ. Stud. 34 (6), 2728-2772. doi:10.1093/rfs/ hhaa114

Chernov, M., Graveline, J., Zviadadze, I., 2018. Crash risk in currency returns. J. Financ. Quant. Anal. 53, 137-170.

Chong, Y., Jordà, Ò., Taylor, A.M., 2012. The Harrod-Balassa-Samuelson hypothesis: real exchange rates and their long-run equilibrium. Int. Econ. Rev. 53, 609-634.

Cochrane, J.H., 2008. The dog that did not bark: a defense of return predictability. Rev. Financ. Stud. 21 (4), 1533-1575. doi:10.1093/rfs/ hhm046.

Cochrane, J.H., 2011. Presidential address: discount rates. J. Finance 66 (4), 1047-1108.

Della Corte, P., Riddiough, S.J., Sarno, L., 2016. Currency premia and global imbalances. Rev. Financ. Stud. 29 (8), 2161-2193. doi:10.1093/ rfs/hhw038.

Della Corte, P., Sarno, L., Sestieri, G., 2012. The predictive information content of external imbalances for exchange rate returns: how much is it worth? Rev. Econ. Stat. 94 (1), 100-115. doi:10.1162/REST_a_00157.

Du, W., Tepper, A., Verdelhan, A., 2018. Deviations from covered interest rate parity. J. Finance $73,915-957$.

Eichenbaum, M.S., Johannsen, B.K., Rebelo, S.T., 2021. Monetary policy and the predictability of nominal exchange rates. Rev. Econ. Stud. 88, $192-228$. 
Engel, C., 2014. Exchange rates and interest parity. In: Gopinath, G., Helpman, E., Rogoff, K. (Eds.), Handbook of International Economics, Volume IV. Elsevier, Amsterdam, pp. 453-522.

Engel, C., 2016. Exchange rates, interest rates, and the risk premium. Am. Econ. Rev. 106 (2), 436-474.

Engel, C., West, K.D., 2005. Exchange rates and fundamentals. J. Polit. Econ. 113 (3), 485-517. doi:10.1086/429137.

Engel, C., West, K.D., 2010. Global interest rates, currency returns, and the real value of the dollar. Am. Econ. Rev. Pap. Proc. 100 (2), 562-567.

Engel, C., Wu, S. P. Y., 2020. Liquidity and exchange rates: an empirical investigation. NBER working paper 25397.

Fama, E.F., 1984. Forward and spot exchange rates. J. Monet. Econ. 14 (3), 319-338. doi:10.1016/0304-3932(84)90046-1.

Farhi, E., Gabaix, X., 2016. Rare disasters and exchange rates. Q. J. Econ. 131 (1), 1-52.

Frankel, J.A., Rose, A.K., 1995. Empirical research on nominal exchange rates. In: Grossman, G.M., Rogoff, K. (Eds.), Handbook of International Economics, Volume III. Elsevier, Amsterdam, pp. 1689-1729.

Froot, K.A., Ramadorai, T., 2005. Currency returns, intrinsic value, and institutional-investor flows. J. Finance 60 (3), 1535-1566. doi:10.1111/ j.1540-6261.2005.00769.x.

Gourinchas, P.-O., Rey, H., 2007. International financial adjustment. J. Polit. Econ. 115 (4), 665-703. doi:10.1086/521966

Hamilton, J.D., 1994. Time Series Analysis. Princeton University Press, Princeton, NJ.

Hansen, L.P., Hodrick, R.J., 1980. Forward exchange rates as optimal predictors of future spot rates: an econometric analysis. J. Polit. Econ. 88 (5), 829-853. doi:10.1086/260910.

Henn, C., Papageorgiou, C., Romero, J.M., Spatafora, N., 2020. Export quality in advanced and developing economies: evidence from a new data set. IMF Econ. Rev. 68, 421-451.

Hsieh, D.A., 1984. Tests of rational expectations and no risk premium in forward exchange markets. J. Int. Econ. 17, 173-184.

Jiang, Z., Krishnamurthy, A., Lustig, H., 2021. Foreign safe asset demand and the dollar exchange rate. J. Finance 76 (3), 1049-1089.

Jordà, Ò., Taylor, A.M., 2012. The carry trade and fundamentals: nothing to fear but FEER itself. J. Int. Econ. 88 (1), 74-90. doi:10.1016/j.jinteco. 2012.03.001.

Kostakis, A., Magdalinos, T., Stamatogiannis, M.P., 2015. Robust econometric inference for stock return predictability. Rev. Financ. Stud. 28, 1506-1533.

Kremens, L., Martin, I., 2019. The quanto theory of exchange rates. Am. Econ. Rev. 109, 810-843.
Lane, P.R., Milesi-Ferretti, G.M., 2004. The transfer problem revisited: net foreign assets and real exchange rates. Rev. Econ. Stat. 86 (4), 841-857. doi: $10.1162 / 0034653043125185$.

Lane, P.R., Milesi-Ferretti, G.M., 2007. The external wealth of nations mark II: revised and extended estimates of foreign assets and liabilities, 1970-2004. J. Int. Econ. 73 (2), 223-250.

Londono, J.M., Zhou, H., 2017. Variance risk premiums and the forward premium puzzle. J. Financ. Econ. 124, 415-440.

Magdalinos, T., Phillips, P.C., 2009. Limit theory for cointegrated systems with moderately integrated and moderately explosive regressors. Econ. Theory 25, 482-526.

Mark, N.C., 1995. Exchange rates and fundamentals: evidence on longhorizon predictability. Am. Econ. Rev. 85 (1), 201-218. doi:10.1126/ science.151.3712.867-a.

Menkhoff, L., Sarno, L., Schmeling, M., Schrimpf, A., 2012. Currency momentum strategies. J. Financ. Econ. 106, 660-684.

Menkhoff, L., Sarno, L., Schmeling, M., Schrimpf, A., 2017. Currency value. Rev. Financ. Stud. 30, 416-441.

Moskowitz, T.J., Ooi, Y., Pedersen, L.H., 2012. Time series momentum. J. Financ. Econ. 104, 228-250.

Newey, W.K., West, K.D., 1987. A simple, positive semi-definite, heteroskedasticity and autocorrelation consistent covariance matrix. Econometrica 55, 703-708.

Rogoff, K.S., 1996. The purchasing power parity puzzle. J. Econ. Lit. 34 (2), 647-668. doi: $10.2307 / 2729217$.

Rossi, B., 2013. Exchange rate predictability. J. Econ. Lit. 51 (4), 1063-1119. doi:10.1257/jel.51.4.1063.

Rytchkov, O., 2012. Filtering out expected dividends and expected returns. Q. J. Finance 2 (03), 1250012.

Schorfheide, F., Song, D., Yaron, A., 2018. Identifying long-run risks: a Bayesian mixed-frequency approach. Econometrica 86, 617-654.

Stambaugh, R.F., 1999. Predictive regressions. J. Financ. Econ. 54 (3), 375-421.

Taylor, A.M., Taylor, M.P., 2004. The purchasing power parity debate. J. Econ. Perspect. 18, 135-158.

Verdelhan, A., 2010. A habit-based explanation of the exchange rate risk premium. J. Finance 65 (1), 123-146. doi:10.1111/j.1540-6261.2009. 01525.x.

White, H.L., 1980. A heteroskedasticity-consistent covariance matrix estimator and a direct test for heteroskedasticity. Econometrica 48 (4), 817-838. 